\title{
Electrocardiogram of Rickets
}

\author{
First Report .
}

\section{INTRODUCTION}

It is not necessary to emphasize that rickets is closely related to other diseases in children. The problem of low serum calcium content in rachitic cases has been taken up so eagerly by many authors that the study on the electrolytes in rachitic patients has now come to the fore, and change appearing on electrocardiograms, for such cases have become a favorite theme of recent studies in this field, because they are closely related to the contents of electrolytes. The author undertook the study reported in the following for the purpose of elucidating the changes in the heart and its function in rachitic children and in Tohoku District by means of electrocardiography.

\section{Method and Subject}

A PC 2 type Eika ECG meter, adjusted to the standard sensitivity of $1 \mathrm{~m} . \mathrm{v}$ $=1 \mathrm{~cm}$ was used. The subject was laid at rest in a dorsal position and his standard limb induction was recorded. The QT-ratio by Goldberger's QTratio Nomogram was measured and if the ratio exceeded 0.19 , the QT duration was elevated as prolonged. For the computation of the electric axis, the Diagram by Wenckebach and Winterberg was used as reference.

As test subjects, 73 children were selected from among the rachitic children and infants who entered Tohoku University Hospital and who were diagnosed as such at the mass-examinations of infants and children in Miyagi Prefecture.

From among these subjects, 20 eutrophic-rachitic, 17 dystrophic rachitic, 35 mild rachitic and 25 severely rachitic infants and children were chosen for comparative study of their ECG. EGG were also taken of 20 children who were diagnosed at the Pediatric Clinic of Tohoku University to be in normal health and the records were used for control.

\section{Results}

\section{Forms of the Curves}

As shown in Table 207, the heights of the waves P.Q.R.S. and T showed no difference between normal and rachitic children.

The waves for eutrophic-rachitic and dystrophic-rachitic cases are not much different, as shown in Table 208, no marked lowering of the $\mathrm{T}$ wave being observed.

Yoshio Hongo, M. D. (Department of Pediatrics, Tohoku University Medical School, Sendai, Japan. Director: Prof. Tamotsu Sano) 


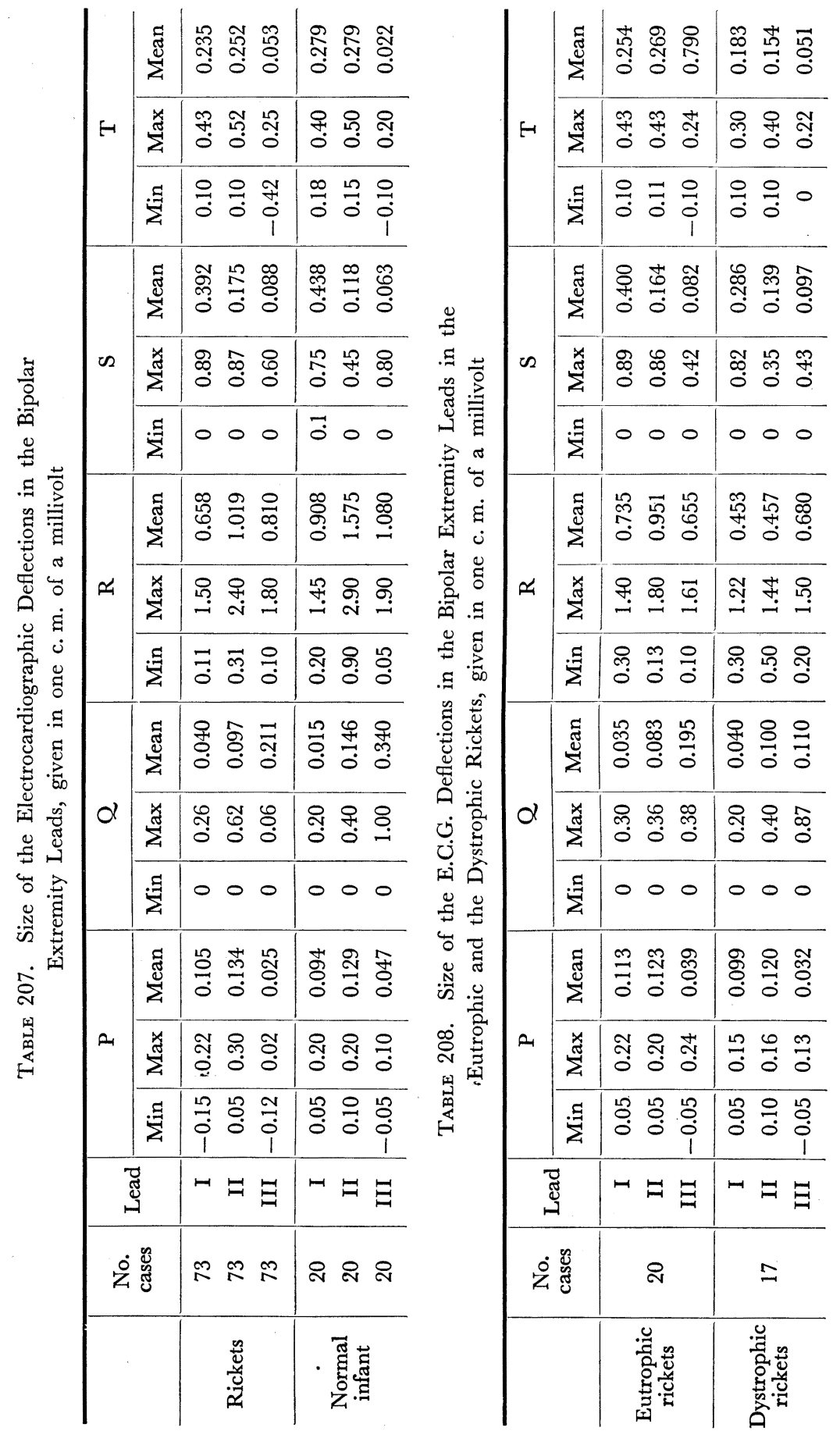


According to the severity of the rickets, no marked difference in the wave was observed. In mild rachitic cases, a lowering of either $\mathrm{T}_{2}$ or $\mathrm{T}_{3}$ was observed, but no simultaneous lowering of the two was ever observed in any of the inductions.

2. Temporary Relation of the Curves

As shown in Table 210, the minimum values of the distance between $P$ waves and QRS complexes are shortened in rachitic in comparison with normal infants, but the mean values are not much different. No case showed a disturbed atrio-ventricular conduction time. No perceptible difference was observed in eutrophic and dystrophic rachitic cases, as shown in Table 211. The changes observed by the severity of rickets were of no significance as shown in Table 112.

3. Electric Axis

Whereas all the normal subjects, as shown in Table 213, showed normal electric axis among the rachitic infants, $8.2 \%$ of the total number showed deviations to the left and $13.6 \%$ to the right of the axes.

4. QT Duration

As stated above, the QT-ratio which I used in the determination of anomalies in QT time, stood at 1.02 on an average in normal infants, only one case showing a value of 1.09 , as shown in Table 214 . In rachitic infants and children the mean QT-ratio was 1.031, showing a duration over the normal value. The dystrophic-rickets showed the value 1.029, longer than that of eutrophic-rachitic children and infants 1.017, showing a greater prolongation QT duration. The severe rachitic subjects showed a mean value of 1.053, and in comparison with the value 1.023 of mild rachitic infants and children, a longer prolongation of QT time in the former was obvious.

A pathological prolongation of the QT time was found only in $5 \%$ of the healthy controls, but such a prolongation was apparent in $21.9 \%$ of the total rachitic subjects, in $15 \%$ of the eutrophic-rachitic, in $23.5 \%$ of the dystrophicrachitic, in $14.2 \%$ of the light rickets and in $14.2 \%$ of the severe rachitic cases.

5. Anomaly in ST and T

No one either in the normal or in the rachitic group showed pathological rise or fall in ST. Some cases showed negative result on the lead III, in respect of the $\mathrm{T}$ wave, but none of them could be deemed as pathological.

\section{Discussion}

In 1931, Hoshi reported on the ECG of 30 rachitic cases, in which he said no perceptible anomaly was found in the EGG, but a predominance of the right ventricle was observable in $10 \%$ of the subjects. I derived the electric axis of QRS in my tests by means of the nomogram by Wenkebach and Winterberg, and thereby found the axes deviated to the left in $8.2 \%$ and to the right in $13.6 \%$ of 73 cases. With respect to the wave forms and timely relation of the curves, I found no changes, worth mentioning as with the case of Hoshi. In particular, the absence of anomaly in ST junction and $\mathrm{T}$ wave suggests that none of the rickets cases was complicated with troubles in the myocardium, and that rickets 


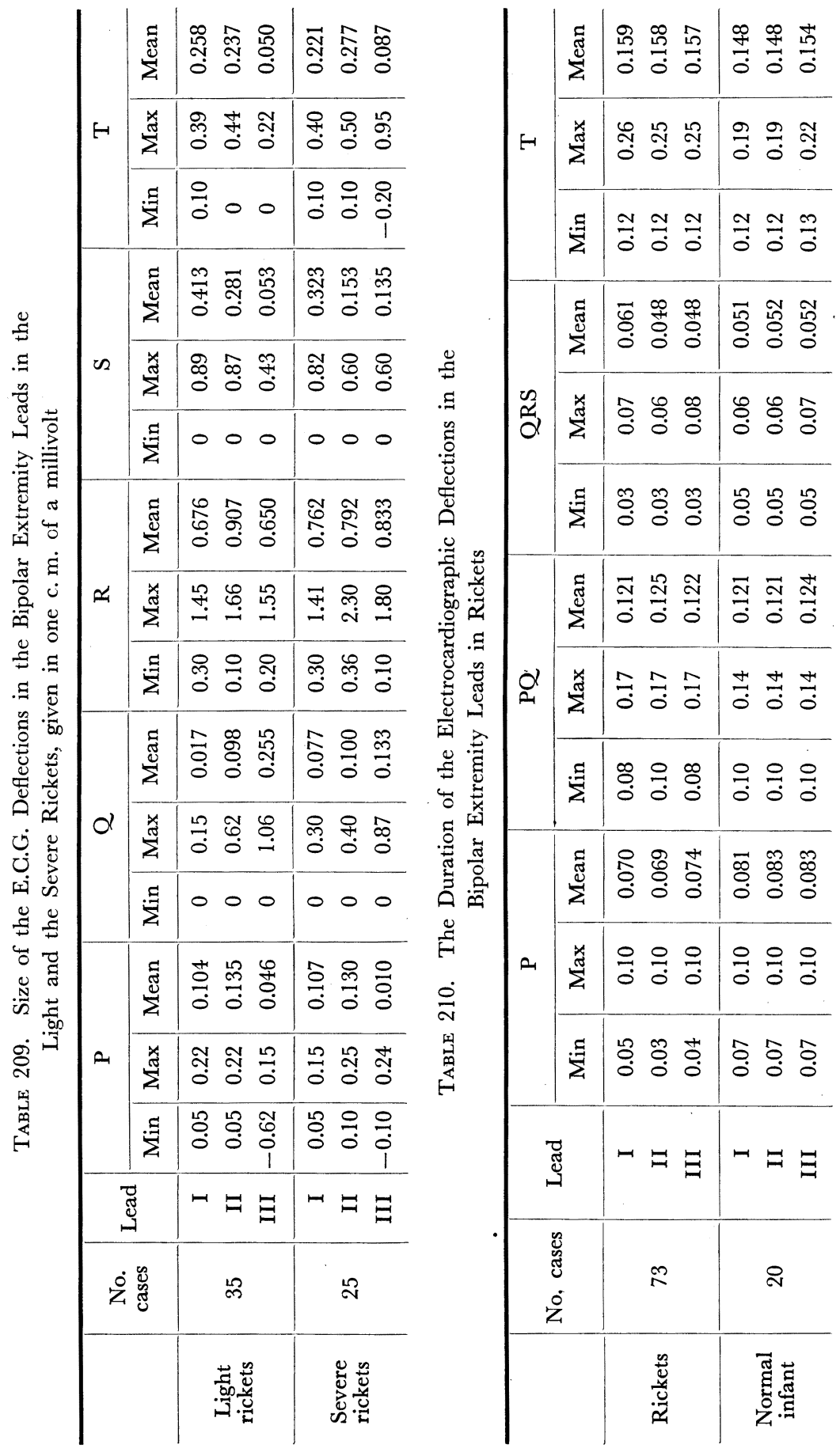




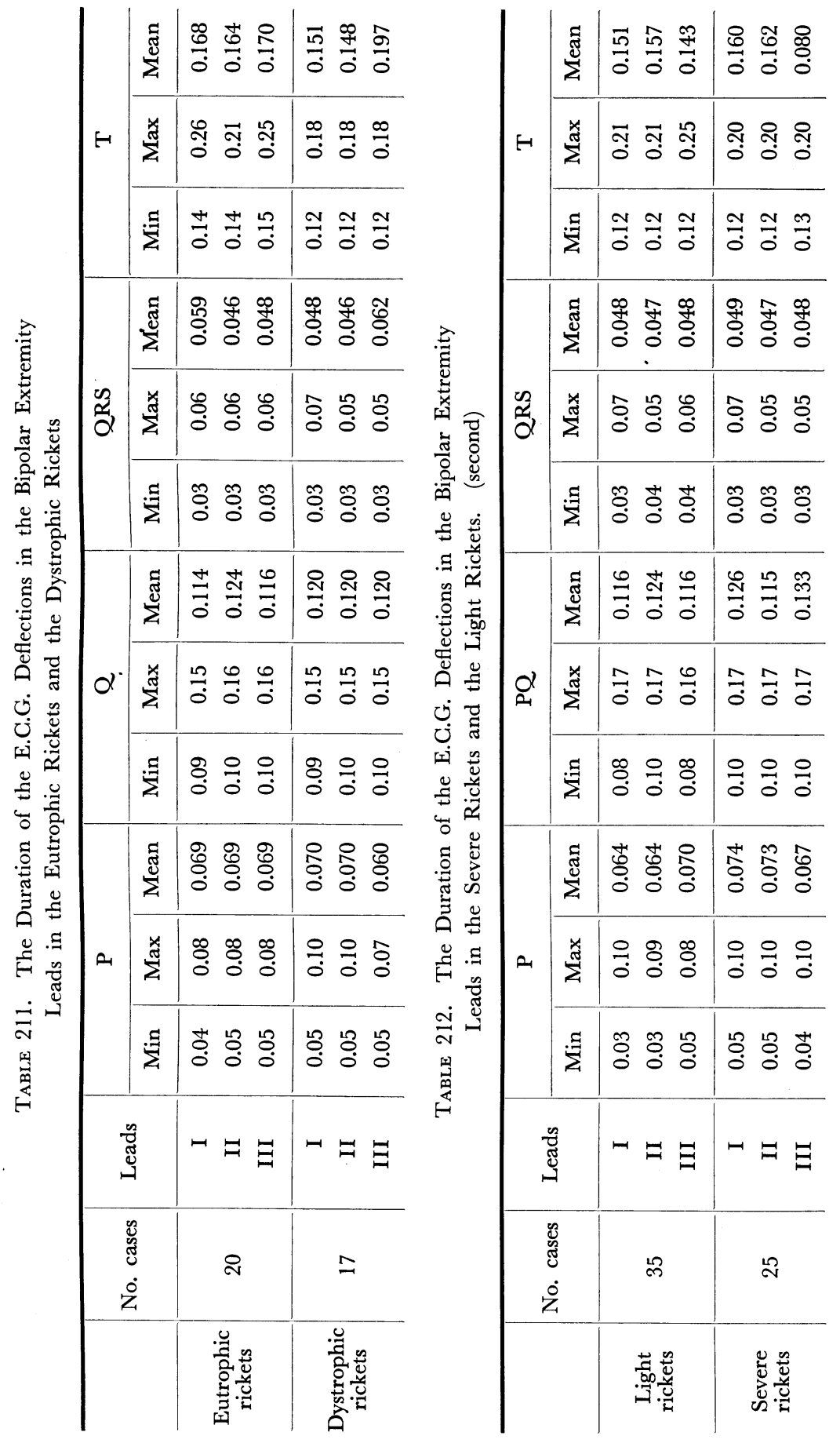


TABle 213. Electric Axis Deviation in Rickets

\begin{tabular}{l|c|c|c|c}
\hline & $\begin{array}{c}\text { No. } \\
\text { cases }\end{array}$ & $\begin{array}{l}\text { Left axis } \\
\text { deviation }\end{array}$ & $\begin{array}{l}\text { Normal axis } \\
\text { deviation }\end{array}$ & $\begin{array}{l}\text { Right axis } \\
\text { deviation }\end{array}$ \\
\hline Rickets & 73 & $6(8.2 \%)$ & $57(78.0 \%)$ & $10(13.6 \%)$ \\
$\begin{array}{l}\text { Normal } \\
\text { infants }\end{array}$ & 20 & 0 & $20(100.0 \%)$ & 0
\end{tabular}

TABLE 214. The QT Duration in Rickets

\begin{tabular}{l|c|c|c|c|c}
\hline & No. & \multicolumn{3}{|c|}{ QT-ratio } & $\begin{array}{c}\text { Prolon- } \\
\text { gation } \\
(\%)\end{array}$ \\
\cline { 2 - 5 } & & Min & Max & Mean & (\%) \\
\cline { 2 - 5 } Rickets & 73 & 0.89 & 1.19 & 1.031 & 21.9 \\
$\begin{array}{l}\text { Nutritious } \\
\text { rickets }\end{array}$ & 20 & 0.89 & 1.14 & 1.017 & 15.0 \\
$\begin{array}{l}\text { Dystrophic } \\
\text { rickets }\end{array}$ & 17 & 0.90 & 1.19 & 1.029 & 23.5 \\
$\begin{array}{l}\text { Light } \\
\text { rickets }\end{array}$ & 35 & 0.89 & 1.15 & 1.023 & 14.2 \\
$\begin{array}{l}\text { Severe } \\
\text { rickets }\end{array}$ & 25 & 0.92 & 1.19 & 1.053 & 36.0 \\
$\begin{array}{l}\text { Normal } \\
\text { infants }\end{array}$ & 20 & 0.90 & 1.09 & 1.020 & 5.0 \\
\end{tabular}
ing in the subjects, it might be attributed to the reduced serum Ca contents.

\section{ConCLUSION}

Upon examination of 73 rachitic children and infants in Tohoku District by ECG, the following results were obtained:

1. No perceptible anomaly is observed in the forms of the deflections in their ECG.

2. No anomaly in their myocardium can be observed.

3. No disturbance in the atrio ventricular conduction time was observed, but a prolongation of QT duration was observed in $21.9 \%$ of the subjects.

4. The above prolongation of QT duration tends to be found more frequently in dystrophic rachitic and severely rachitic cases.

\section{EGG Study of Ricket in Tohoku District}

Second Report

\section{INTRODUCTION}

I have reported in my first report that the prolongation of QT time is the chief anomaly observable in the ECG of a rachitic case has been stated in my 
first report, and that this prolongation of QT time may be attributed to the decrease of serum $\mathrm{Ca}$, from the commonly observed reduction of the Ca content in serum in rachitic cases. It is, then, of interest to investigate the relation between the changes in serum $\mathrm{Ca}$ and QT duration. I performed, therefore, tetany induction tests on rachitic cases for the purpose of determining the changes in QT time due to a change in the serum Ca content.

\section{Method and Subject}

To take ECG, a $\mathrm{PC}_{2}$ type Eika ECG meter, adjusted to the standard sensitivity of $1 \mathrm{~m} . \mathrm{v}=1 \mathrm{~cm}$, was used. The subject lay on the back and after the tetany induction test, ECG was registered every 3 hours.

To determine anomaly in QT time, the QT-ratio was calculated, in the same way as described in my first report.

The subjects were selected from among severe rachitic children as in the previous study, and upon oral administration of secondary phosphate of sodium, 7 children in whom positive tetanic reaction was induced were subjected to examination by ECG. (The doses of phosphate was $0.5 \mathrm{gr}$ per $\mathrm{Kg}$ body weight, and children in whom plain tetany fits were induced in 30 to 60 minutes were deemed positive).

\section{Results}

As shown in Table 207, the QT-ratio in tetany positive rachitic cases stood at 1.053 on an average before the induction test, but one hour after it, the ratio rose to 1.14 , in 3 hours to 1.17 and came down to 1.11 in 6 hours. This shows that the QT time is prolonged maximally 3 hours after the test. After

TABLE 215. The QT Ratio in Tetany Positive Rachitic Cases

\begin{tabular}{|c|c|c|c|c|c|c|c|}
\hline Case & Age & Sex & $\begin{array}{c}\text { Grade } \\
\text { of } \\
\text { rickets }\end{array}$ & $0 \mathrm{hr}$ & $1 \mathrm{hr}$ & $3 \mathrm{hrs}$ & $6 \mathrm{hrs}$ \\
\hline $\begin{array}{c}1 \\
2 \\
3 \\
4 \\
5 \\
6 \\
7 \\
\text { Mean }\end{array}$ & $\begin{array}{r}2-0 \\
2-6 \\
4-9 \\
1-8 \\
3-4 \\
13-9 \\
2-3\end{array}$ & 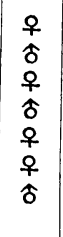 & $\begin{array}{l}+ \\
H \\
H \\
H \\
H \\
\text { H } \\
\text { H }\end{array}$ & $\begin{array}{l}1.05 \\
1.1 \\
1.02 \\
1.05 \\
1.015 \\
1.06 \\
1.08 \\
1.053\end{array}$ & $\begin{array}{l}1.12 \\
1.20 \\
\overline{1.17} \\
- \\
\overline{1.08} \\
1.14\end{array}$ & $\begin{array}{l}1.06 \\
1.23 \\
1.21 \\
1.24 \\
1.16 \\
1.18 \\
1.12 \\
1.17\end{array}$ & $\begin{array}{l}1 . \overline{21} \\
1.11 \\
1.06 \\
1.12 \\
1.08 \\
1.10 \\
1.11\end{array}$ \\
\hline
\end{tabular}

TABLE 216. The QT Ratio in Normal Children in Tetany Induction Test

\begin{tabular}{|c|c|c|c|c|c|c|}
\hline Case & Age & Sex & $0 \mathrm{hr}$ & $1 \mathrm{hr}$ & $3 \mathrm{hrs}$ & $6 \mathrm{hrs}$ \\
\hline 1 & $1-6$ & 우 & 1.03 & 1.06 & 1.07 & 0.98 \\
\hline 2 & $2-2$ & $\hat{\delta}$ & 1.0 & 1.14 & 1.12 & 1.04 \\
\hline Mean & & & 1.015 & 1.10 & 1.095 & 1.01 \\
\hline
\end{tabular}

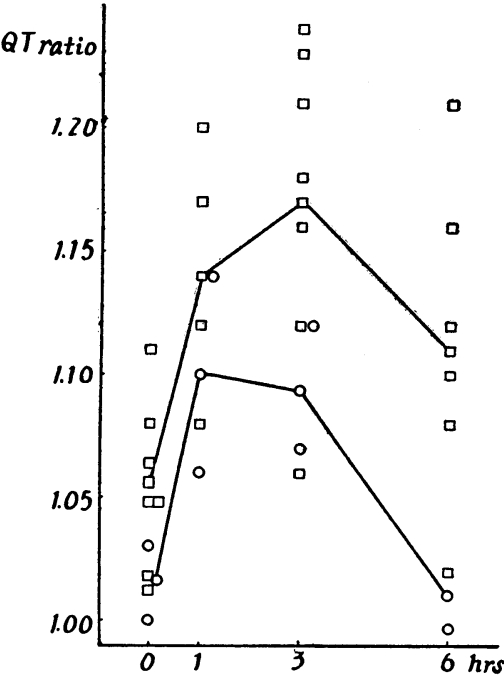

Fig. 140. The QT ratio in tetany induction test in rachitic and normal children. 
Case 4 ly $8 m$ o
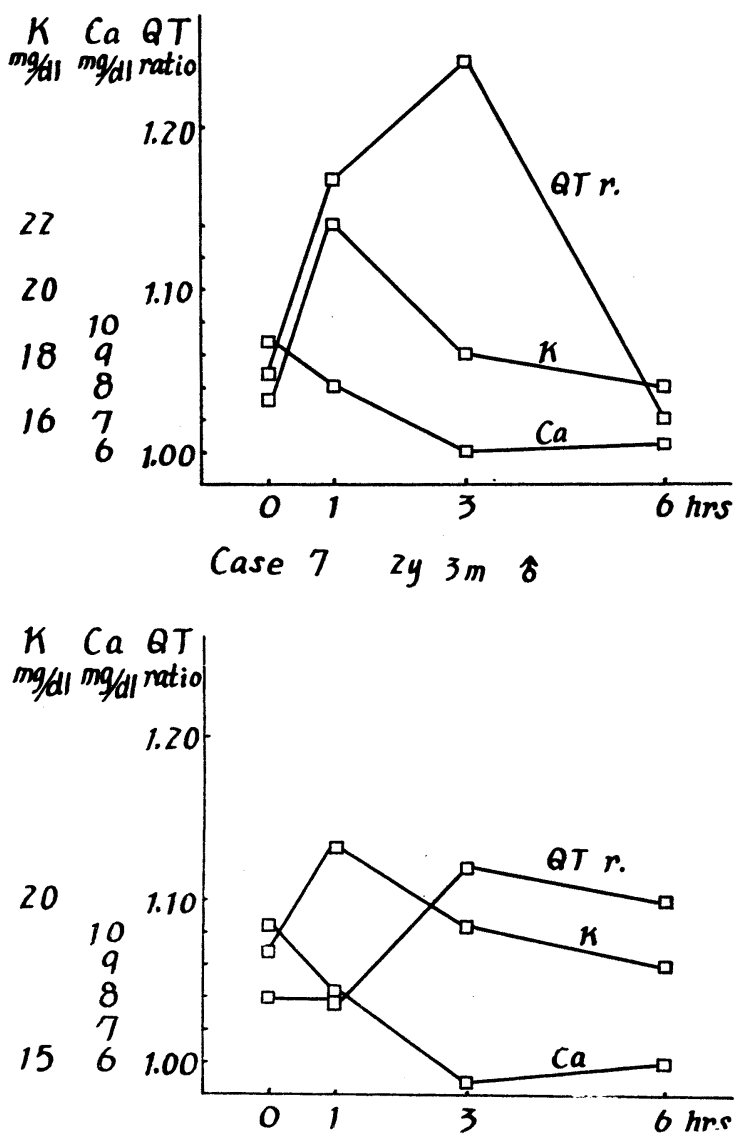

Fig. 141. The relation between the QT ratio and the serum $\mathrm{Ca}$ and $\mathrm{K}$ contents in tetany positive rickets. similar tests, the QT-ratio in normal children rose to 1.10 from the original 1.015, in one hour remained at 1.095 for 3 hours and fell to 1.01 in 6 hours. That is to say, the QT time is prolonged 1-3 hours after the test in normal children too.

The blood pressure of the tested infants and children ranged between $120 \mathrm{mmHg}$ and $95 \mathrm{mmHg}$ throughout, no abnormalities of blood pressure being observed.

No perceptible difference was observed in the atrioventricular conduction time before and after the tests, suggesting no disturbance in the transmission.

No marked changes were observable in $P, Q, R, S$ and $\mathrm{T}$ waves, in ST-junctions. The duration of QRS complexes showed no anomaly either.

\section{Summary and Discussion}

The contents of electrolytes in serum have a very close bearing on ECG, and, recently the important relation between electrolytes and infantile diseases have been under discussion.

The serum $\mathrm{Ca}$ and $\mathrm{K}$ contents have direct influence on EGG, an increase or decrease of $\mathrm{Ca}$ in serum causing a prolongation of QT time and a change in serum $K$ results in a change in the hight of $T$ wave and of the length of the QT time.

In the case of rickets, the serum calcium content usually falls subnormal, which is also true in Tohoku District, according to M. Sato of this Clinic. Serum $\mathrm{K}$ content is slightly high in rickets in this District, according to a report by $\mathrm{H}$. Abe. In the cases subjected to tetany induction tests, the serum Ca content falls to the lowest level 3 hours after the test as shown in Table 208. The serum $\mathrm{K}$ content shows a temporal elevation in one hour, but recovered to the former value in 6 hours. Thus, the results of the tetany tests, as shown in the changes 
of QT time and serum Ca content, coincide completely, suggesting the decrease in serum $\mathrm{Ca}$ content as the cause of QT time prolongation. The mean values of QT time are prolonged longer in rachitic than in normal children, and the influence of the tetany induction test on the QT time is more marked in severe rachitic children who have remarkably low serum Ca content.

A change in serum $\mathrm{Ca}$ is apt to affect $\mathrm{T}$ and RS-T, but in this study, no marked change could be found. In tetany reaction, the shortening of $P Q$ time is sometimes observable, while the QT time is always prolonged. In my study, however, no case of appreciable shortening of PQ time was found.

\section{Conclusion}

ECG findings taken after tetany induction tests in rachitic children in Tohoku District were studied, and the following results were obtained:

1. No marked change was found in the deflection of ECG.

2. No signs of disturbance were observed in atrio-ventricular conduction time or in the myocardium.

3. The QT duration in the ECG was subjected to a perceptible change, recording a marked prolongation 3 hours after the test.

4. Such a prolongation of QT duration is mainly attributable to the lowering of the serum Ca content.

\section{REFERENCES}

1) S. Izumi, Acta Paed. Jap., 1931, 374, 84. 2) S. Komoto, Acta Paed. Jap., 1934, 403, 116. 3) N. Hoshi, Acta Paed. Jap., 1931, 377, 148. 4) S. Izumi, Textbook of Pediatrics (Jap.) XI, IV, 1937, 55. 5) W. Brenner, W. Birk., Ztschr. f. Kinderh., 1953, 73, 251. 6) E. Goldberger, Am. Heart. J., 1948, 36, 141. 7) Barker, P. S., Johnston, F. D., and Wilson, F. N., Am. Heart. J., 1937, 14, 82. 8) Ernstene, A. C., Proudfit, W. L., Am. Heart. J., 1949, 38, 260. 9) Ziegler, R. F., Circuration, 1951, 3, 438, 10) M. Sato, unpublished. 11) Y. Abe, unpublished. 12) J. Warkany, Ztschr. f. Kinderh., 1928, 46, 716. 13) J. Warkany, Ztschr. f. Kinderh., 1930, 49, 191. 14) K. Shindhing, Mtschr. f. Kinderh., 1933-34, 59, 245. 15) Hegglin, R., Holzmann, M., Klin. Wchschr., 1937, 16, 1146. 16) Bellet, S., Steiger, W. A., Nadler, C. S., and Gażes, P. C., Am. J. M. Sci. 1950, 219, 542. 


\section{Electroencephalographic Findings in Rickets and in Tetany}

\section{INTRODUCTION}

It is widely known that tetanic manifestation is caused by hypocalcemia and alkalosis. In addition to these factors, many other factors such as absorption and excretion of calcium and regulation of calcium metabolism must be taken into consideration. Hypocalcemia in rickets due to vitamin $\mathrm{D}$ deficiency depends upon incomplete absorption of calcium in the upper part of the small intestine.

Tetany generally does not occur in rickets except under a special condition, but does occur only in a limited number of rachitic infants, whose inadequate intake of vitamin $\mathrm{D}_{2}$ is the most frequent cause of tetany and who are complicated by dysfunction of parathyroid induced by high grade hypocalcemia.

The electroencephalographic changes in patients with idiopathic or postoperative hypoparathyroidism were studied by Gotta and Odiiz (1948).1) Klotz et al. $(1955)^{2)}$ and Hansted et al. (1953) ${ }^{3)}$ reported the fact that the electroencephalographic changes in rachitic infants with tetany could be cured by vitamin D therapy.

The present report describes the occurrence of five cases of rickets, three cases of rickets associated with persistent tetany, one of them with tetanic fits induced by provocation and the last one without fits, with special reference to the electroencephalographic features in them.

\section{Clinical Observations}

Case 1: K. I. A female infant, aged one year and six months, was born in normal delivery, weighing $2,600 \mathrm{~g}$ at birth. The patient was bottle fed. The method of feeding was inadequate because of her mother's negligence.

Physical and mental development was, therefore, markedly retarded. According to the mother, the illness of patient was first observed in the form of mild respiratory infection with a little cough on Jan. 28th, 1955. She suddenly cried 2 days later. Characteristic twitchings and tremors in the upper extremities and the rigidity of both legs occurred without convulsion.

The infant was conscious, but profuse sweating and stridor supervened. On Feb. 3rd, the patient was admitted to our clinic.

Physical findings on admission: body weight $7.5 \mathrm{~kg}$, temp. $37.7^{\circ} \mathrm{C}$, nutritional status dystrophic, edema on face observable, no cyanosis.

There were hoarseness of voice and stridor which might be due to laryngeal

Junji Nihei, M. D. (Department of Pediatrics, Tohoku University Medical School, Sendai, Japan. Director : Prof. Tamotsu Sano) 
TABLE 217. (Case 1 K. I. 우, ly6m)

\begin{tabular}{|c|c|c|c|c|}
\hline & \multicolumn{2}{|c|}{ Laboratory findings } & \multicolumn{2}{|c|}{ Normal range } \\
\hline Serum & $\begin{array}{l}\mathrm{Ca} \\
\mathrm{Ca}+ \\
\mathrm{P} \\
\mathrm{Pt} \\
\mathrm{Na} \\
\mathrm{K} \\
\mathrm{Mg} \\
\mathrm{Cl}_{2} \\
\text { Total base } \\
\mathrm{pH} \\
\mathrm{CO}_{2} \\
\mathrm{Cholesterol}_{\text {Total protein }}\end{array}$ & $\begin{array}{c}6.0 \mathrm{mg} / \mathrm{dl} \\
1.35 \mathrm{mg} / \mathrm{dl} \\
3.16 \mathrm{mg} / \mathrm{dl} \\
20.65 \mathrm{~B} . \mathrm{U} . \\
133.5 \mathrm{mEq} / \mathrm{L} \\
5.9 \mathrm{mEq} / \mathrm{L} \\
1.80 \mathrm{mg} / \mathrm{dl} \\
380 \mathrm{mg} / \mathrm{dl} \\
143.9 \mathrm{mEq} / \mathrm{L} \\
7.42 \mathrm{Vol} \% \\
19.5 \mathrm{~V} / \mathrm{m} \\
220 \mathrm{mg} / \mathrm{dl} \\
6.12 \mathrm{gr} / \mathrm{dl}\end{array}$ & $\begin{array}{c}10 \mathrm{mg} / \mathrm{dl} \\
3.0-5.0 \mathrm{mg} / \mathrm{dl} \\
4.0-7.0 \mathrm{mg} / \mathrm{dl} \\
5.0-10.0 \mathrm{~B} . \mathrm{U} . \\
133-143 \mathrm{mEq} / \mathrm{L} \\
4.0-5.5 \mathrm{mEq} / \mathrm{L} \\
2.0 \mathrm{mg} / \mathrm{dl} \\
355-376 \mathrm{mg} / \mathrm{dl} \\
143-150 \mathrm{mEq} / \mathrm{L} \\
7.40 \\
40-60 \mathrm{Vol} \% \\
170-200 \mathrm{mg} / \mathrm{dl} \\
6.5-7.5 \mathrm{gr} / \mathrm{dl}\end{array}$ & $\begin{array}{l}\downarrow \\
\downarrow \\
\downarrow \\
\stackrel{\downarrow}{=} \\
\uparrow \\
= \\
\stackrel{\uparrow}{=} \\
= \\
\downarrow \\
\downarrow\end{array}$ \\
\hline whole blood & $\begin{array}{l}\mathrm{Fe} \\
\text { Sugar } \\
\mathrm{H}_{2} \mathrm{O} \\
\text { N.P.N. } \\
\text { Creatinine }\end{array}$ & $\begin{array}{l}27.1 \mathrm{mg} / \mathrm{dl} \\
72 \mathrm{mg} / \mathrm{dl} \\
83.5 \mathrm{\%} \\
21.5 \mathrm{mg} / \mathrm{dl} \\
0.69 \mathrm{mg} / \mathrm{dl}\end{array}$ & $\begin{array}{l}47-55 \mathrm{mg} / \mathrm{dl} \\
70-100 \mathrm{mg} / \mathrm{dl} \\
79-81 \% \\
25-40 \mathrm{mg} / \mathrm{dl} \\
0.5-2.0 \mathrm{mg} / \mathrm{dl}\end{array}$ & $\stackrel{\downarrow}{=}$ \\
\hline spinal fluid & $\begin{array}{l}\text { Turbidity } \\
\text { Pressure } \\
\text { Cell count } \\
\text { Glob. react. } \\
\mathrm{Ca} \\
\mathbf{P} \\
\mathrm{Mg} \\
\mathrm{Cl}_{2}\end{array}$ & \begin{tabular}{l}
\multicolumn{2}{c}{ clear } \\
300 \\
$6 / 3 \quad \mathrm{mmH}_{2} \mathrm{O}$ \\
$\quad(\mathrm{L} / \mathrm{N}=6 / 0)$ \\
$3.65 \mathrm{mg} / \mathrm{dl}$ \\
$1.71 \mathrm{mg} / \mathrm{dl}$ \\
$2.7 \mathrm{mg} / \mathrm{dl}$ \\
$432 \quad \mathrm{mg} / \mathrm{dl}$
\end{tabular} & $\begin{array}{c}\text { clear } \\
70-200 \mathrm{mmH}_{2} \mathrm{O} \\
\text { within } 10 / 3 \\
- \\
4.0 \overline{\mathrm{mg}} / \mathrm{dl} \\
1.5 \mathrm{mg} / \mathrm{dl} \\
2.5 \mathrm{mg} / \mathrm{dl} \\
415-435 \mathrm{mg} / \mathrm{dl}\end{array}$ & $\begin{array}{l}\bar{\uparrow} \\
= \\
= \\
\downarrow \\
= \\
= \\
=\end{array}$ \\
\hline Urine & $\begin{array}{l}\text { Daily excretion } \\
\text { pH } \\
\text { S.G. } \\
\text { Ca. } \\
\text { P. } \\
\text { Creatinine } \\
\text { Greatine } \\
\text { Indican }\end{array}$ & $\begin{array}{cl}290 & \mathrm{cc} \\
7.4 & \\
1025 & \\
1.2 & \mathrm{mg} / \mathrm{kg} \\
27.1 & \mathrm{mg} / \mathrm{kg} \\
155 & \mathrm{mg} / \mathrm{kg} \\
54 & \mathrm{mg} \\
& +\end{array}$ & $\begin{array}{c}400-500 \mathrm{cc} \\
5-7 \\
\text { within } 1022 \\
5.0 \mathrm{mg} / \mathrm{kg} \\
15 \mathrm{mg} / \mathrm{kg} \\
7-10 \mathrm{mg} / \mathrm{kg} \\
10-50 \mathrm{mg} \\
\text { small amount }\end{array}$ & $\uparrow$ \\
\hline Liver function & $\begin{array}{l}\text { Icterus index } \\
\text { Cobalt reaction } \\
\text { Thymol turbidity test } \\
\text { Brom sulfalein test }\end{array}$ & $\begin{array}{ll}6.5 & \mathrm{U} \\
\mathrm{R}_{0} & \\
1 & \% \\
31 & \%\end{array}$ & $\begin{array}{l}4-6 \mathrm{U} \\
\mathrm{R}_{3}-\mathrm{R}_{4} \\
0-4 \% \\
0-5 \%\end{array}$ & $\begin{array}{l}\stackrel{\uparrow}{\text { Shift to }} \\
\text { left } \\
= \\
=\end{array}$ \\
\hline Feces & $\begin{array}{l}\text { Ca. } \\
\text { P. } \\
\text { Fat contents } \\
\text { percent } \\
\text { Fat, dried weight }\end{array}$ & $\begin{array}{rl}905 & \mathrm{mg} \\
91.7 & \mathrm{mg} \\
8.6 & \mathrm{~g} \\
26.8 & \%\end{array}$ & $\begin{array}{c}563 \mathrm{mg} \\
172 \mathrm{mg} \\
1.04 \pm 0.41 \mathrm{gm} \\
11.0-25.5 \%\end{array}$ & $\begin{array}{l}\uparrow \\
\downarrow \\
\uparrow\end{array}$ \\
\hline \multicolumn{2}{|c|}{ Thorn test } & $38 \%$ & more than $50 \%$ & $\downarrow$ \\
\hline \multicolumn{2}{|c|}{$\begin{array}{l}\text { Hardness of bone } \\
\text { by Sano's osteometer }\end{array}$} & $1.2 \mathrm{~kg}$ & $3.20-5.50 \mathrm{~kg}$ & $\downarrow$ \\
\hline Gastric juice & $\begin{array}{l}\mathrm{HCl} \\
\text { Free HCl } \\
\text { Occult bleeding }\end{array}$ & $\begin{array}{r}6.0 \\
0 \\
-\end{array}$ & $\begin{array}{r}11.0 \\
5.0 \\
-\end{array}$ & $\stackrel{\downarrow}{\downarrow}$ \\
\hline $\begin{array}{l}\text { Peripheral } \\
\text { blood }\end{array}$ & $\begin{array}{l}\text { R.B.C. } \\
\text { Hematocrit } \\
\text { Hb } \\
\text { W.B.C. }\end{array}$ & $\begin{array}{c}6.55^{104} \\
40.2 \% \\
15.3 \mathrm{~g} / \mathrm{dl} \\
9200\end{array}$ & $\begin{array}{c}4.6^{10^{4}} \pm 0.710^{4} \\
35 \pm 5 \\
11.2 \mathrm{gm} / \mathrm{dl} \\
8000-16500\end{array}$ & $\begin{array}{l}\stackrel{\uparrow}{=} \\
\stackrel{\uparrow}{=}\end{array}$ \\
\hline
\end{tabular}

Note: $\downarrow$ : indicates the lowered value than in the normal.

$\uparrow$ : indicates the higher value than in the normal.

$=:$ indicates the normal value. 
spasm. The development of the teeth was delayed severely by dental caries and the defect in the enamel. The anterior fontanel was widely opened. Rosary and Harrison's groove were elicited markedly. The characteristic position of the upper extremities called accoucheur's hand was revealed. Epiphysis was enlarged. The foot extended in bow legs and talipes equinovarus.

Trousseau's and Chvostek's signs, were both positive. Peroneal sign was markedly noted. Laboratory data are presented in Table 217. Total calcium in the serum was $6.0 \mathrm{mg} / \mathrm{dl}$ and ionised calcium $1.35 \mathrm{mg} / \mathrm{dl}$. These findings were much lower than the normal. In line with them, the electrical threshold of the ulnar and the peroneal nerve were distinctly lowered (Fig. 142).

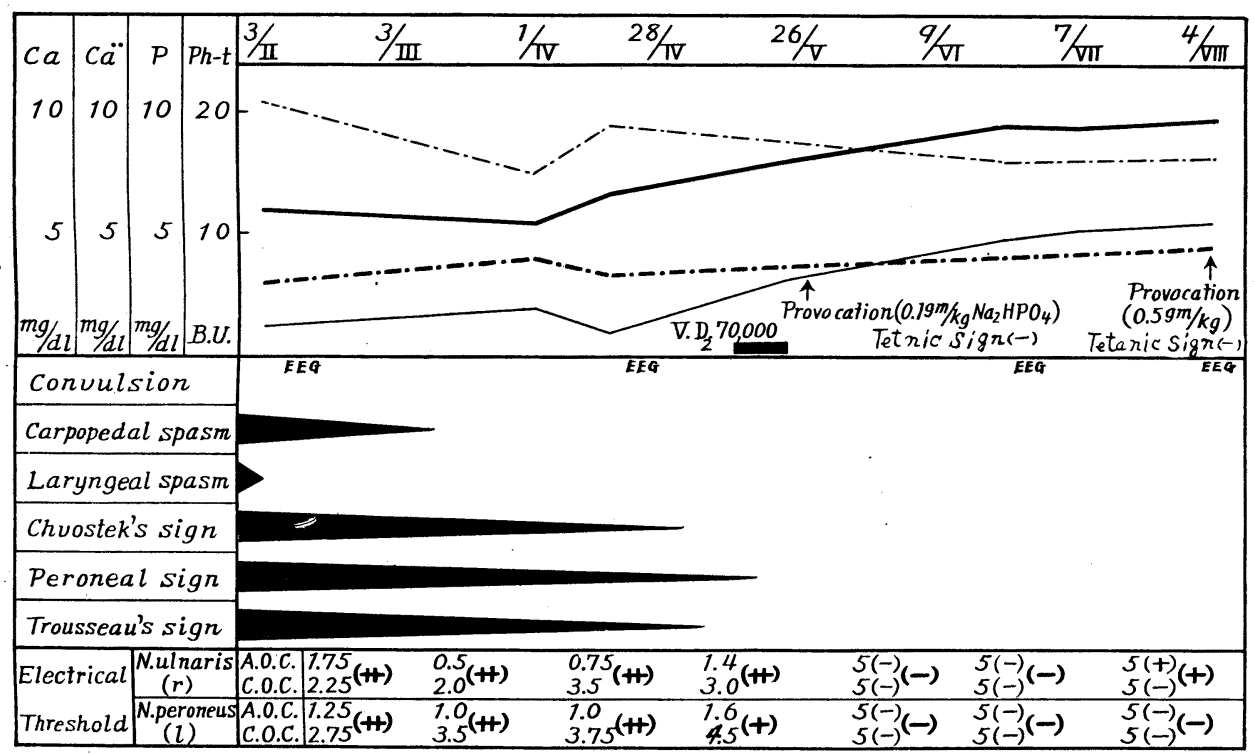

Fig. 142. Chemical findings of $\mathrm{Ca}, \mathrm{Ca}$, $\mathrm{P}$ and Pt. in Serum and Clinical course.

Phosphorus in serum: $3.16 \mathrm{mg} / \mathrm{dl}$. Alkalme phosphatase : 20.65 B. U. abnormally high. Spinal fluid revealed no pathological findings except an increase in the pressure. Calcium in urine was small in amount, while phosphorus increased. Fecal excretion of total fat was greater in amounts than the normal. The hardness of the bone measured by Sano's Osteometer was reduced. Roentogenograms of the bone were as shown in Figs. (143-146.) The normal epiphyseal line disappeared and poor calcification of skeleton was elicited in faint shadows. A wide zone of uncalcified tissue could be seen between the epiphysis and diaphysis. Consequently, at the end of the bone, cupping and frayed features, characteristics in rickets, could be elicited.

In electrocardiograms, PQ interval was prolonged, being $0.18 \mathrm{sec}$. QT ratio was 1.09 , which means a prolongation of the conduction time (Fig. 147 and 7). 


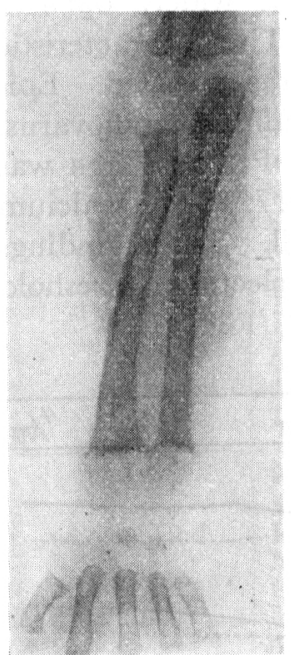

A

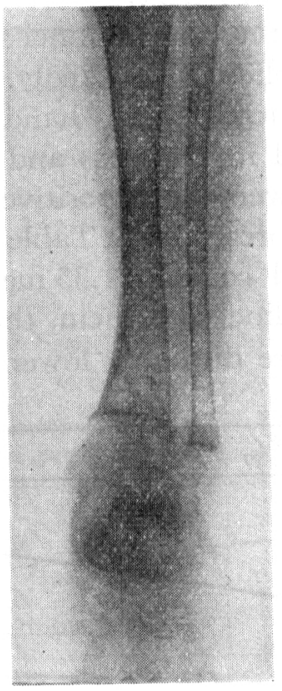

B

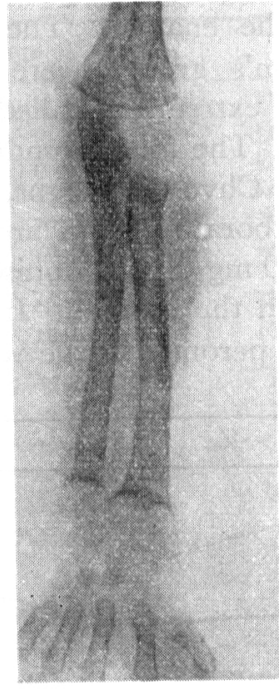

C

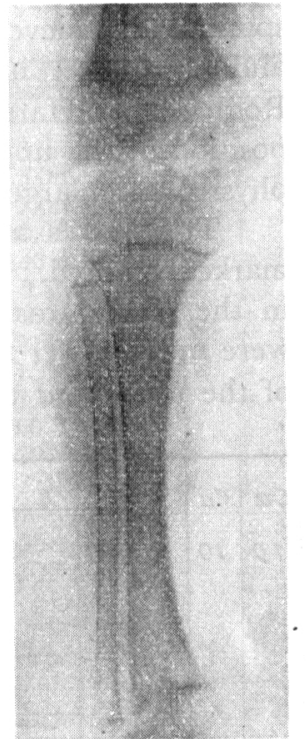

$\mathrm{D}$

Fig. 143. Rachitic X-ray findings in case 1. Photos A \& B, on Feb. 3rd, 1955, on admission. Photos C \& D, taken on March 3rd, 23 days after admission. Rachitic epiphysis, frayed, epiphyseal line disappeared, faint shadow of osteoporosis.

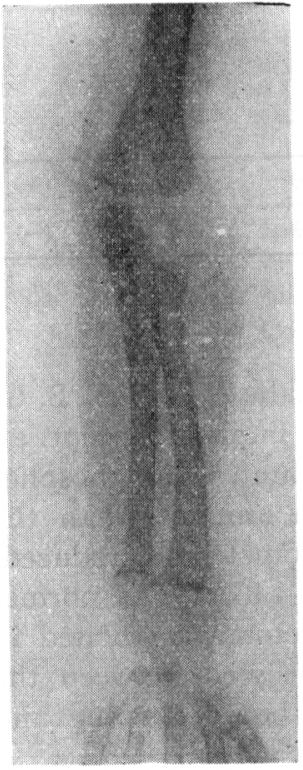

E

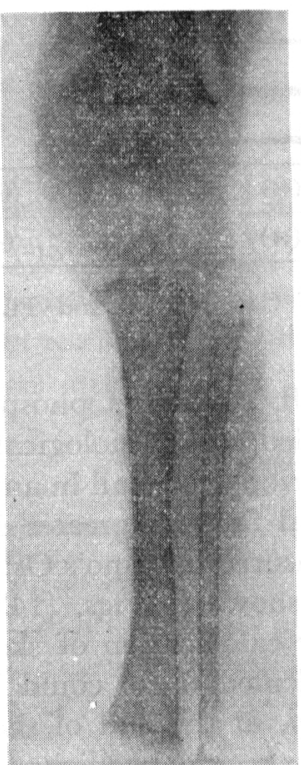

$\mathbf{F}$

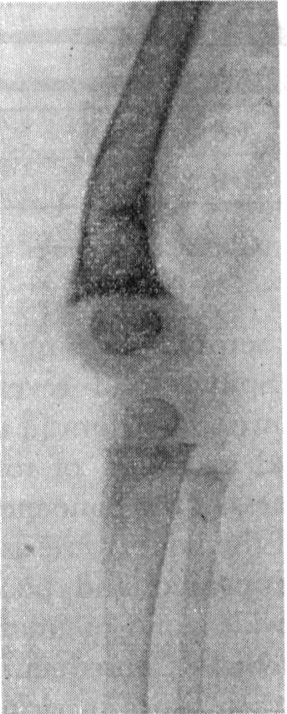

G

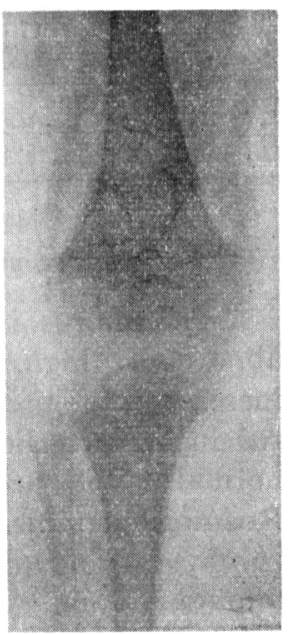

$\mathrm{H}$

Fig. 144. Rachitic X-ray findings in case 1. Photo, E \& F, taken at 27, March, 46th day after admission, rachitic changes exist. Photos. G \& H, taken on April 29th, 1955, show bone fractures in Humerus. 


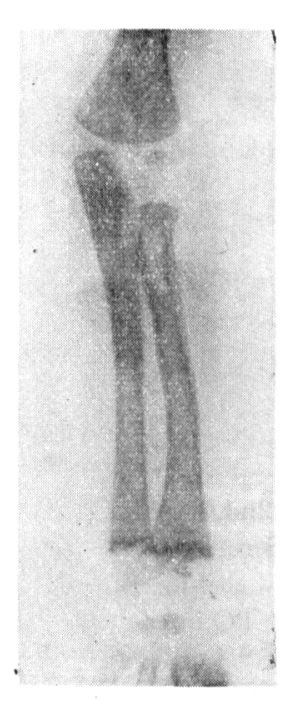

I

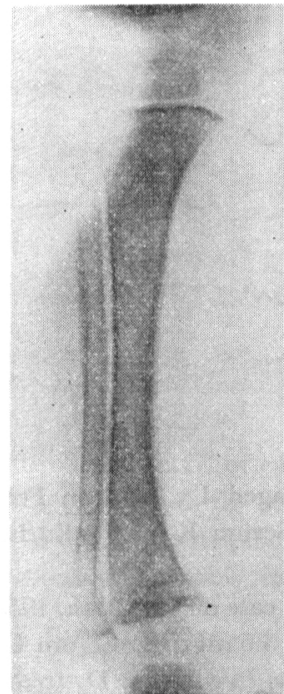

J

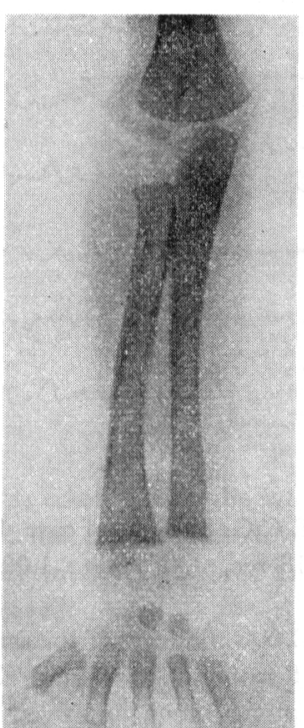

K

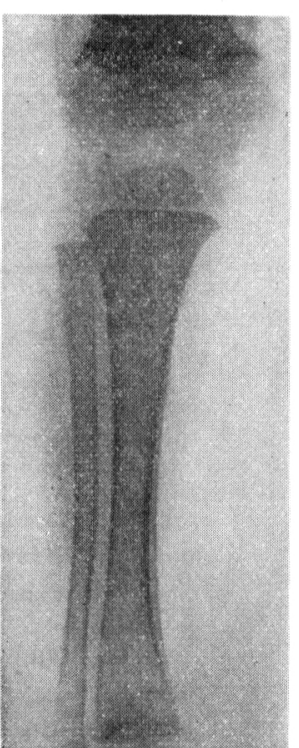

L

Fig. 145. Rachitic X-findings in case 1. Photos I \& J, taken on June 29th, 1955, 52 days after vitamin $\mathrm{D}_{2}$ treatment, show appearances of provisional zone of calcification in epiphysis. Photos K \& L, taken on July 10th, 1955. Epiphyseal line and center of ossification appeared.

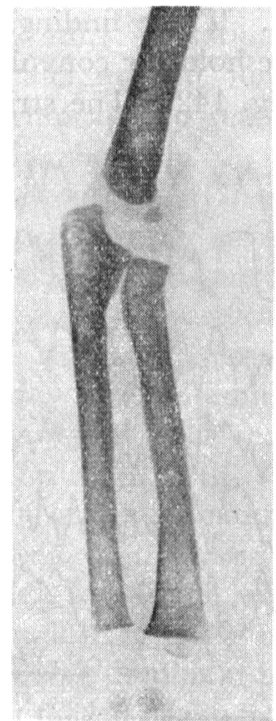

M

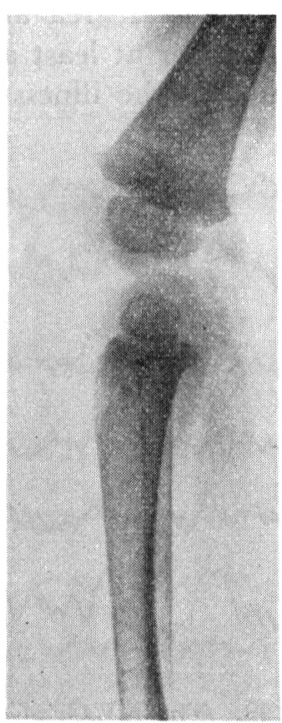

$\mathrm{N}$

Fig. 146. Rachitic X-ray findings in Case 1. Photos $\mathbf{M} \& \mathbf{N}$, taken 95 days after vitamin $\mathrm{D}_{2}$ treatment, at the time of discharge. 
Fig. 147

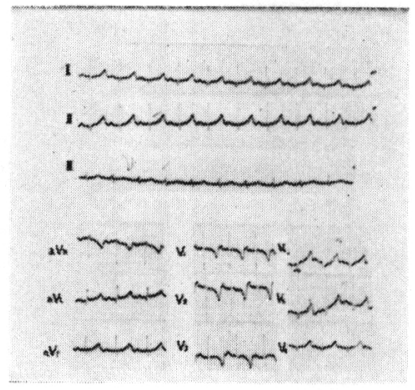

Fig. 148

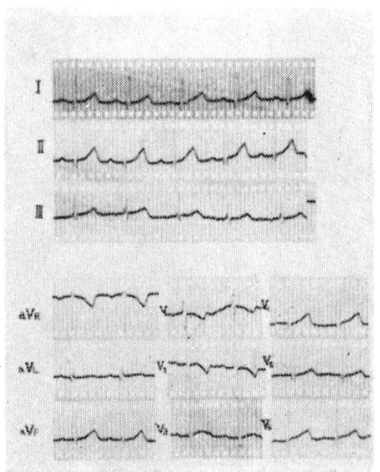

Fig. 147. E.C.G. findings of case 1, aged 1 y $6 \mathrm{~m}$. on Feb. 2nd, 1955. PQ interval : $0.18 \mathrm{sec}$, QT ratio : 1.09 , Serum K : $5.9 \mathrm{mEq} / \mathrm{L}$, Serum $\mathrm{Ca}$ : $6.0 \mathrm{mEq} / \mathrm{L}$.

Fig. 148. E.C.G. findings of the same case on July 27th, 1955. PQinterval : $0.17 \mathrm{sec}$, QT ratio : 1.16 , Serum K : $3.6 \mathrm{mEq} / \mathrm{L}$, Serum Ca : $9.4 \mathrm{mEq} /$

L. Clinical symptoms much improved due to vitamin $\mathrm{D}_{2}$ treatment.

An E.E.G. taken during the tetanic manifestation was as shown in Fig. 149. It revealed sporadic slow waves or high voltage slow waves in all leads, and when pentothal was administered orally during light sleep, there appeared a spike, a wave complex or sharp waves, which were predominant in the right frontocentral area. Accordingly, it was concluded that there was a focal brain damage in the right frontocentral area and the vertex. These findings suggested the suspicions of epilepsy or at least a decrease threshold for convulsion.

Patient's course of the illness is given in Fig. 142. The stridor which was

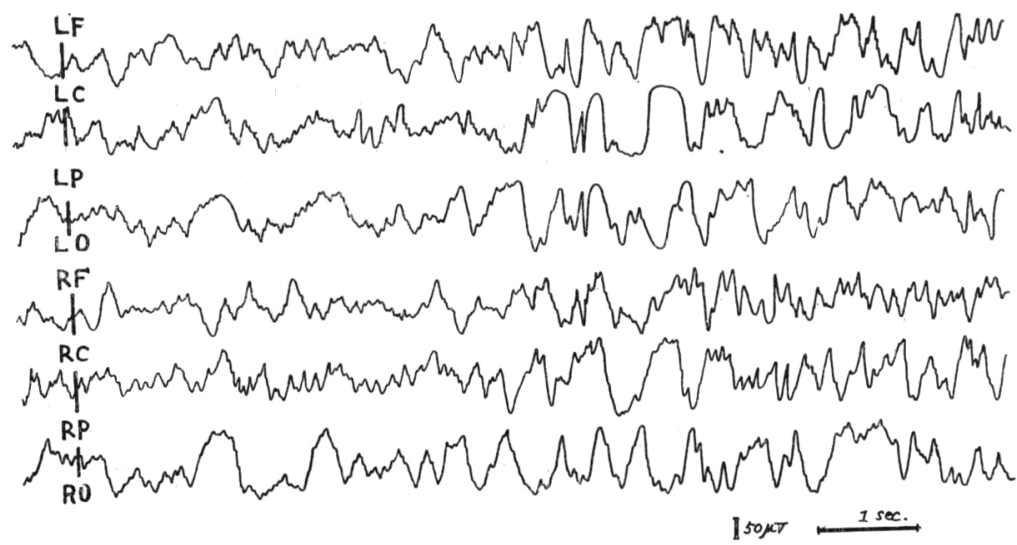

Fig. 149. The E.E.G. of case 1, K. I. a female infant, aged 1 yr. $6 \mathrm{~m}$, taken on admission, during the tetanic manifestation, on Feb. 5th, 1955, showing nonparoxysmal continuous high voltage slow waves, $2-3 \mathrm{c} / \mathrm{s}$, in all leads, sharp and wave complex localized in left side, and asymmetry. 


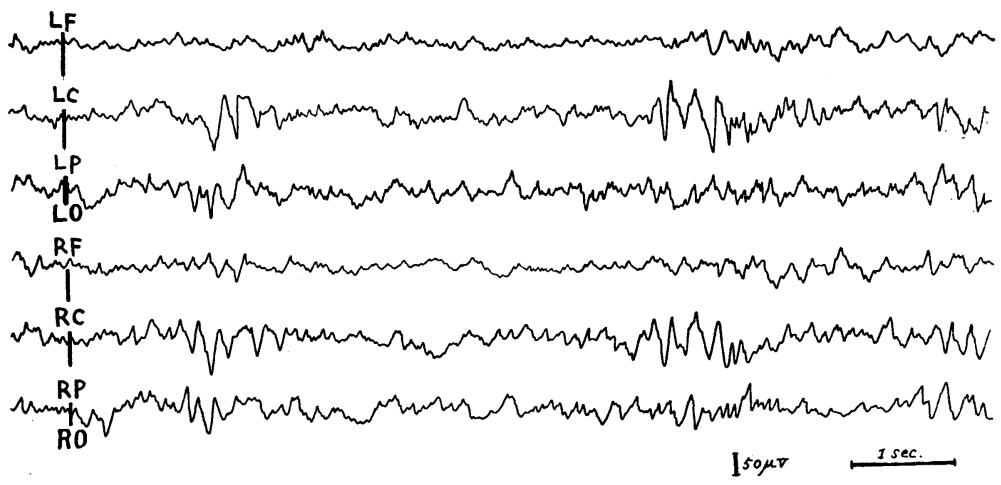

Fig. 150. The E.E.G. of case 1, taken during the latent stage of tetany, on April 27th, 1955, showing occasional paroxysmal slow waves with high amplitude, $4-5 \mathrm{c} / \mathrm{s}$, without spike and wave complex and asymmetry. Generally basic pattern remarkably improved.

considered to be a laryngeal spasm disappeared in 3 days. The carpopedal spasm gradually decreased with other clinical signs and the disease shifted to the state of latent tetany 30 days after the admission.

Electrical excitability was recovered to the normal in examination on June 28th. Variations in total serum calcium and ionized calcium and clinical sign reflected on them were as shown in Fig. 142.

A spontaneous bone fracture of the humerus took place on April 28th. (Fig. 146). Appearances of the provisional zone of calcification were observed in roentgenograms at the 52nd day after vitamin $\mathrm{D}_{2}$ treatment (Fig. 145). The second E.E.G. taken on April 27th, 1955, under sleep by oral application of pentothal showed, on the basic pattern of fast high amplitude waves, sporadic slow and sharp waves in all leads, though being dominant in its abnormality in the left frontocentral area. Such findings as those described above seemed to exceed the normal limits, though an asymmetry

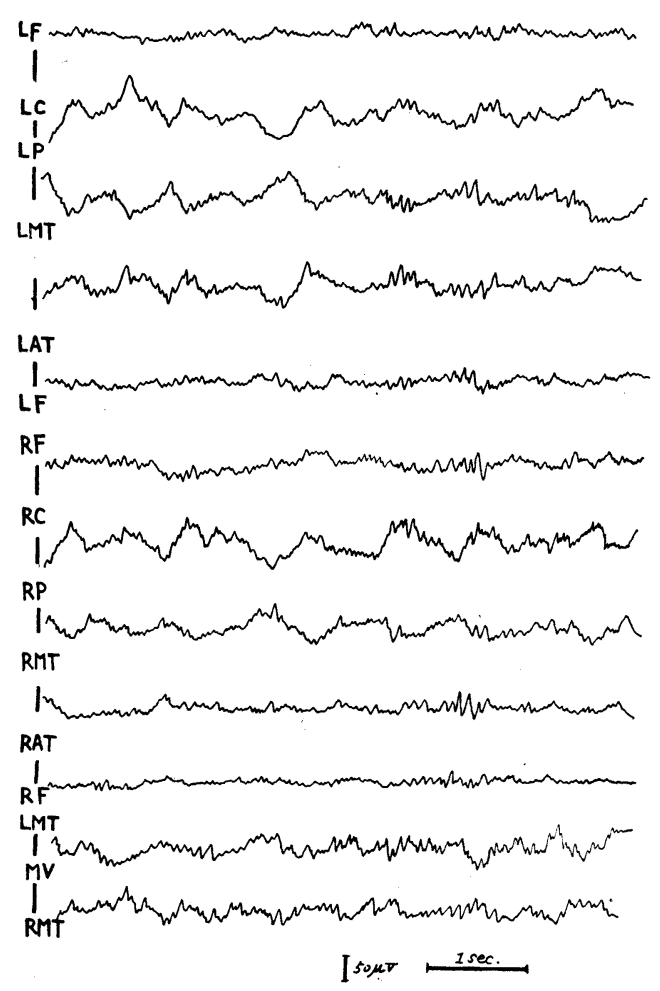

Fig. 151. The E.E.G. of case 1, taken on June 23rd, 1955, showing the regular waves of about $12 \mathrm{c} / \mathrm{s}$. No pathological findings of E.E.G. 


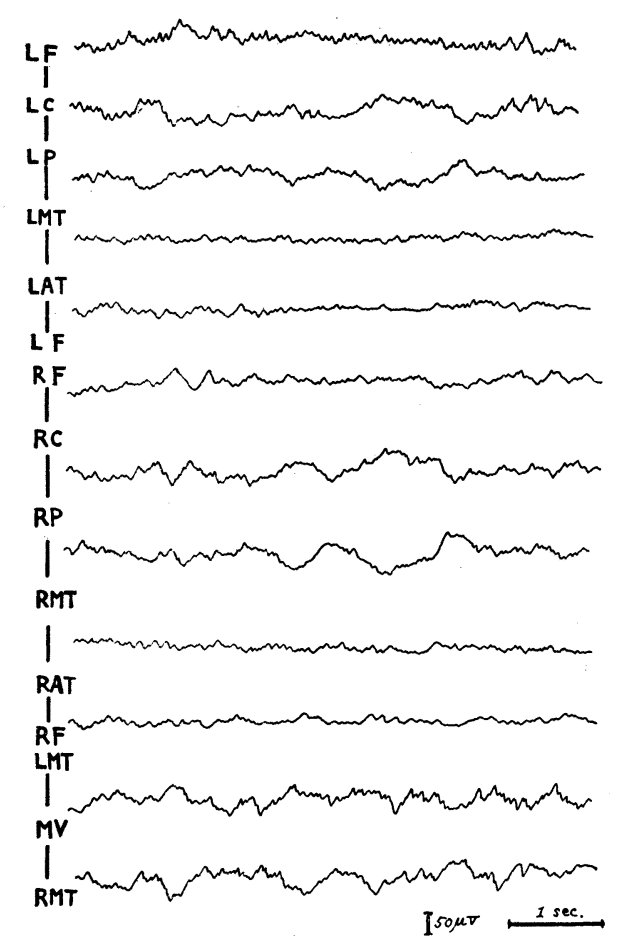

Fig. 152. The E.E.G. of case 1, taken on Aug. 9th, 1955, showing no abnormalities within normal limits as that found in third E.E.G. is occasionally recognizable in the infantile stage. Accordingly, the focal brain damage was suspected. In the previous E.E.G. findings, the focus was localized in the right frontocentral area, but in the second record, it shifted to the left frontocentral area. (Fig. 150).

In third E.E.G. taken on June 23rd 1955, during sleep following pentothal, the sharp wave or spike and wave complex disappeared, which were recognized in the previous E.E.G. Occasionally, there was a burst of $10 \mathrm{c} / \mathrm{sec}$ postitive spiky waves in the frontal and temporal area. Accordingly, it was concluded that the electroencephalographic changes recovered from the brain damage. (Fig. 151).

The sleep recording of E.E.G. taken on Aug. 9th, 1955 showed rhythms rather within normal limits and sporadic slow waves of $4-5 \mathrm{c} / \mathrm{sec}$ in posterior part, without spiky waves.

Generally, the E.E.G. recovered within normal limits. (Fig. 152).

Case 2: M.S. A female infant,

aged 2 months and 25 days, was born after 8 months gestation with breech delivery, weighing $1,820 \mathrm{~g}$ at birth: her feeding was artificial.

The patient suffered from icterus gravis on the 20th day of life, and thereafter icterus increased day by day. On the 37 th day of life suddenly a generalized convulsion occurred, followed by twitchings of facial muscles, intermittent tremor of upper extremities and unconciousness.

These symptoms occurred 4 or 5 times a day, lasting for 1 minute.

The convulsion was gradually reduced four weeks after the onset. On March 9th, 1955, the patient was admitted in our clinic.

On admission the patient was found to be dystrophic. The facies were like those of the aged. The craniotabes and rosary were markedly observed. The rigidity of the upper extremities presented themselves with convulsion and unconsciousness. Chvostek's and Trousseau's signs were markedly positive and the peroneus reflex exaggerating.

Laboratory findings were as shown in Table 218. Calcium and ionized calcium in serum distinctly decreased, while phosphorus was within the normal limit. Electrical excitability of the ulnar and peroneal nerves markedly in- 
TABle 218. (Case 2: M. S. 우, $2 \mathrm{~m}, 25$ days)

\begin{tabular}{|c|c|c|c|c|c|}
\hline & & \multicolumn{2}{|c|}{$\begin{array}{l}\text { On March 19th-26th, } \\
1955\end{array}$} & On April 13th, & On May 10 th, \\
\hline \multirow[t]{2}{*}{ Serum } & $\begin{array}{l}\mathrm{Ca} \\
\mathrm{Ca}+ \\
\mathrm{P} \\
\mathrm{Pt} \\
\mathrm{Mg} \\
\mathrm{Cl}\end{array}$ & \multicolumn{2}{|c|}{$\begin{array}{c}5.70 \mathrm{mg} / \mathrm{dl} \\
1.15 \mathrm{mg} / \mathrm{dl} \\
5.19 \mathrm{mg} / \mathrm{dl} \\
11.09 \mathrm{B.u} \\
1.3 \mathrm{mg} / \mathrm{dl} \\
388 \mathrm{mg} / \mathrm{dl}\end{array}$} & $\begin{array}{c}5.45 \mathrm{mg} / \mathrm{dl} \\
1.45 \mathrm{mg} / \mathrm{dl} \\
5.17 \mathrm{mg} / \mathrm{dl} \\
14.94 \mathrm{B.u} \\
1.45 \mathrm{mg} / \mathrm{dl} \\
-\end{array}$ & $\begin{array}{c}7.20 \mathrm{mg} / \mathrm{dl} \\
2.80 \mathrm{mg} / \mathrm{dl} \\
5.10 \mathrm{mg} / \mathrm{dl} \\
10.03 \mathrm{B.u} . \\
\ldots \\
-\end{array}$ \\
\hline & $\begin{array}{l}\text { Sugar in } \\
\text { blood }\end{array}$ & \multicolumn{2}{|c|}{$66 \mathrm{mg} / \mathrm{dl}$} & - & - \\
\hline \multirow{2}{*}{$\begin{array}{l}\text { Electrical } \\
\text { threshold }\end{array}$} & N. ulnaris & $\begin{array}{l}\text { A.O.C. } \\
\text { C.O.C. }\end{array}$ & $\underset{1.5 \mathrm{~mA}}{1.5 \mathrm{~mA}}(H)$ & - & more than $5 \mathrm{~mA}(-)$ \\
\hline & N. peroneus & $\begin{array}{l}\text { A.O.C. } \\
\text { C.O.C. }\end{array}$ & $\frac{1.5 \mathrm{~mA}}{5.0 \mathrm{~mA}}(+)$ & - & more than $5 \mathrm{~mA}(-)$ \\
\hline
\end{tabular}

Laboratory findings showing the lower level of $\mathrm{Ca}$ and Catt in serum, while phosphorus in normal limits and phosphatase increassing slightly. Decrease of electrical threshold of peripheral nerves was found and it was improved after treatment.

creased. In roentgenograms mild rachitic shadow was observed on the ulnar epiphysis. (Fig. 153). Electrocardiograms revealed marked sinus tachycardia, 171/min and QT ratio, 1,11 which means a prolongation of the conduction time.

An E.E.G. taken on March 28th, 1955, showed, under sleep recording by oral pentothal application slow waves $(2 \mathrm{c} / \mathrm{sec})$ frequency recognized in all leads, an asymmetry in the right anterior part in amplitude, and sporadic sharp waves in the right anterior part. Accordingly, it was concluded that there was a brain organic damage in the
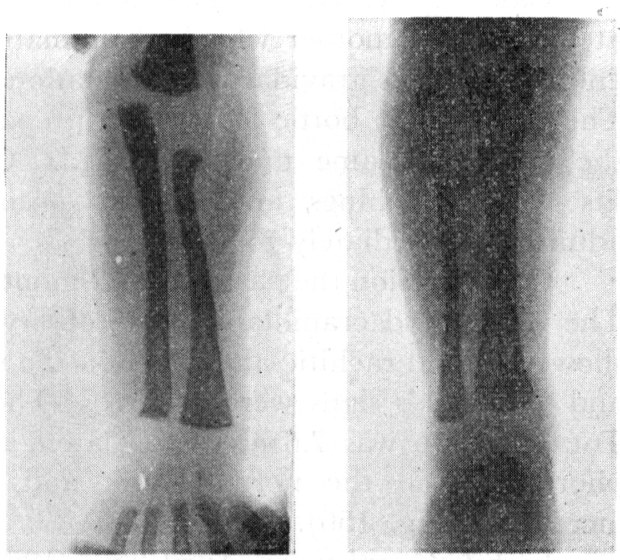

Fig. 153. Rachitic X-ray findings in case 2 . Photos taken on March 22nd, 1955, on admission. Slight rachitic changes in ulnar epiphysis. anterior part of the right hemisphare. (Fig. 154).

On admission no generalized convulsion was presented. On March 26th suddenly an epileptic convulsion occurred, followed by twitchings of facial muscles, conjugate deviation and nystagmus. The laryngeal and carpopedal spasms were not observed. Intravenous administration of calcium gluclonate had no effect on the convulsive seizure. Tetany occured several times a day, persisting for 10 days. Tetanic fits disappeared, 32 days after admission while total calcium of $7.20 \mathrm{mg} / \mathrm{dl}$ and ionized calcium of $2,80 \mathrm{mg} / \mathrm{dl}$ remained on the lower level even 50 days after admission. 


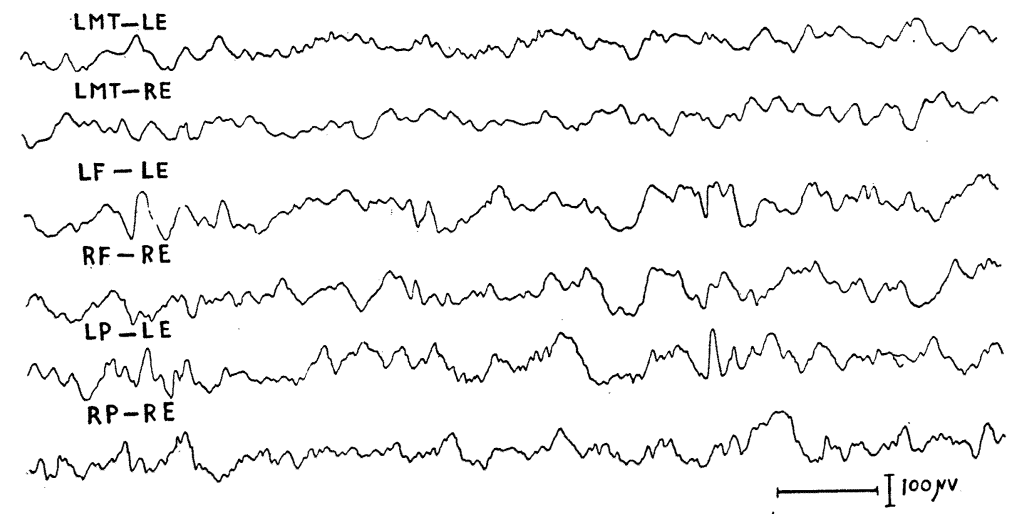

Fig. 154. The E.E.G. of case 2, M. S., aged 3 months and 13 days, taken on Mar. 28th 1955, n sleep induced by pentothal, showing random slow waves, 3-4 c/s, in dominant rhythms of basic pattern mixed with abnormal slow waves below $2 \mathrm{c} / \mathrm{s}$, dominant in right frontal area. Sporadic sharp waves in left parietal area.

Case 3: M. K. A male infant, born as one of twins, weighing $2,600 \mathrm{~g}$ at birth. His mother who had premature rupture in delivery of the patient and hyperemesis gravidarum in gestation suffered from continuous severe anemia. The patient was bottle fed. Milk preparation had been so much diluted that the patient became undernourished. On April 17th, 1953, sudden tetanic fits with twitchings and apnoea occurred every hour. The patient was admitted immediately to our clinic.

On admission the patient was 2 months and 10 day old and weighed 3,550 g. The rosary and craniotabes were observed. X-ray findings of the wrist joint showed a mild rachitic alteration on the ulnar epiphysis (Fig. 155. Trousseua's and Chvostek's signs were positive. There were no changes in the spinal fluid. Total calcium was $7.6 \mathrm{mg} / \mathrm{dl}$ (on latent tetanic level), while $4.4 \mathrm{mg} / \mathrm{dl}$ of phosphorus was in the normal limit and phosphatase was $13.2 \mathrm{~B}$. U. (slightly increased) (Fig. 156).

In E.C.G. taken on April 25th, 1953, QTc of $0.29 \mathrm{sec}$ and PQ interval of $0.13 \mathrm{sec}$, was noted a prolongation of the conduction time. The sleep recording of E.E.G. induced by pentothal (intravenously) revealed high voltage irregular slow activity with spike and sharp burst, especially on the left side. There were sporadic high voltage slow waves, $6 \mathrm{c} / \mathrm{sec}$, on the right side. (Fig. 157).

The patient was diagnosed as hypocalcemic tetany accompanied with mild infantile rickets on the clinical signs and laboratory findings mentioned above. Treatment by the intravenous injection of calcium and of 100,000 units of vitamin $\mathrm{D}_{2}$ brought tetanic fits at a standstill temporarily. 19 and 27 days after admission, generalized convulsions occurred again. At the same time total calcium in serum showed lowered value of $7.6 \mathrm{mg} / \mathrm{dl}$ and electrical excitability obviously increased. Therapy consisted of the administration of vitamin $\mathrm{D}_{2}$ and calcium lactate, and the patient showed no further evidence of tetanic 
fits. The E.E.G. taken on June 13th, 1953, showed that there still remained a difference in both sides, and waves were irregular on the left side. The rhythms were generally improved compared with the previous E.E.G. (Fig. 158).

Case 4: M. M. A female child, aged 3 years and 2 months, weighing $3.100 \mathrm{~g}$ at birth in normal delivery. She was malnourished in infancy, because of insufficient mother's milk and lack of care. She was very retarded physically and could not hold her head and shoulders until 2 years of age. She discriminated strangers at 2 years and a half, and vocalized a few words. She merely asked for a food. Her emotional reaction was very dull. She had no epileptic seizures and asked no toilet needs.

On admission, $10.4 \mathrm{Kg}$ in weight. Rosary and double wrist with enlarged distal end of bone were distinct. Abdomen was distended. Fontanel, was closed. Bow legs were observed. Roentgenograms in wrist joint and feet revelaed characteristic features of severe rickets and retarded appearances of bone centers and in hip joints showed features of coxa vara. Laboratory examinations revealed the following; calcium in serum; $9.0 \mathrm{mg} / \mathrm{dl}$, ionised calcium :

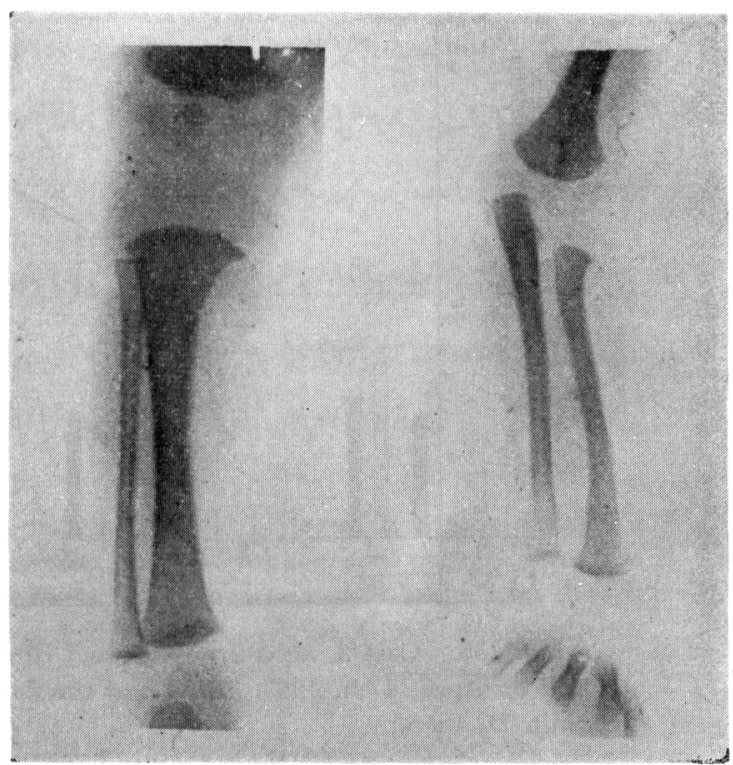

A

B

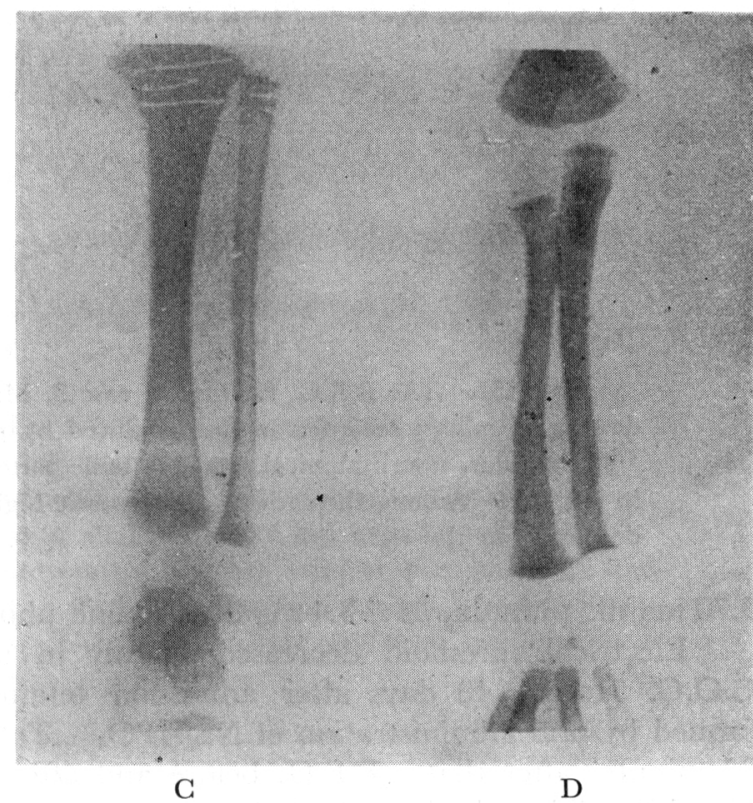

Fig. 155. Rachitic X-ray findings in case 3 . Photos of upper \& lower extremities A \& B, taken on admission. Slight rachitic changes in ulnar end. Photos, C \& D, taken 32 days after admission. Distinct epiphyseal line due to calcium deposit. 


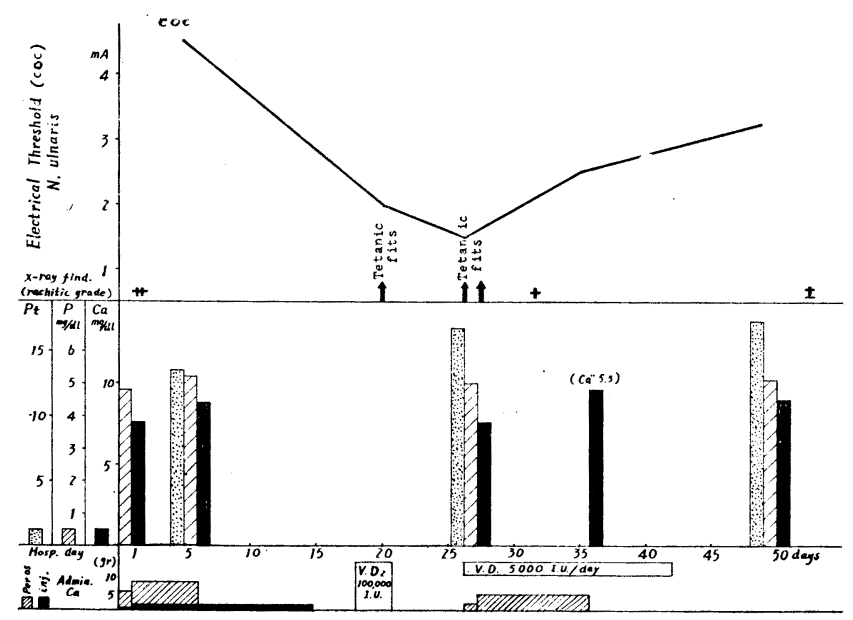

Fig. 156. Case 3, aged 2 months and 10 days, male rachitic infant, admitted on April, 17th, 1953. Electrical threshold, chemical findings by Ca, vitamin $D_{2}$ therapy.

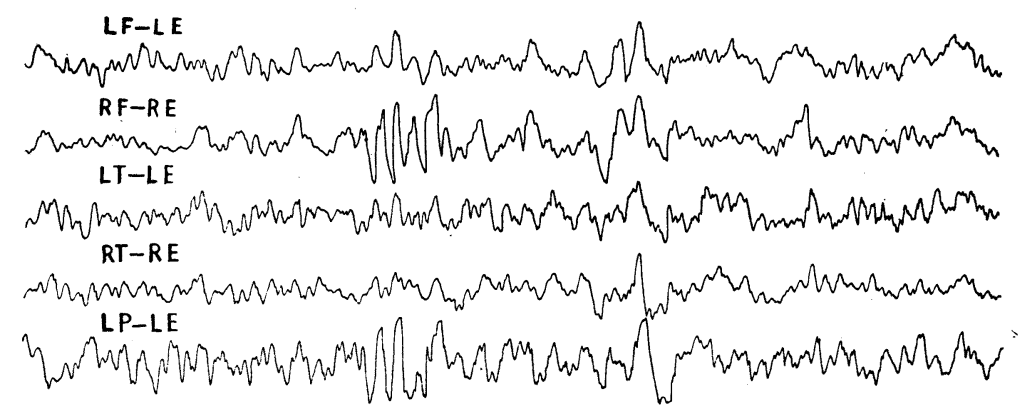

Fig. 157. The E.E.G. findings of case 3, M. K., aged 2 months and 11 days male infant, recorded in sleep induced by pentothal injection.

Irregular, nonrhythmical waves in basic pattern, especially abnormality, in left side. Among them there are sporadic high voltage slow waves, $6 \mathrm{c} / \mathrm{s}$ dominant in the right side.

$3.70 \mathrm{mg} / \mathrm{dl}$, phosphorus : $3.4 \mathrm{mg} / \mathrm{dl}$, alkaline phosphatase ; $22.63 \mathrm{~B}$. U.

Electrical threshold decreased slightly in ulnar nerve (A.O.C. $2.6 \mathrm{~mA}$, C.O.C. $5 \mathrm{~mA}$ ). 48 days after admission tetanic provocation test was performed by oral administration of $\mathrm{Na}_{2} \mathrm{HPO}_{4}$. Tetanic manifestation supervened 20 minutes after that. E.E.G. before and after provocation was as shown in Fig. 159. Though the E.E.G. before tetanic provocation showed regular continuous slow waves of $6-8 \mathrm{c} / \mathrm{s}$ in all leads, the E.E.G. after the provocation revealed abnormalities of localized atypical spike and wave complex of $3 \mathrm{c} / \mathrm{s}$ on right frontotemporal areas. They are regarded as abnormalities commonly considered as features of epileptic seizure. 


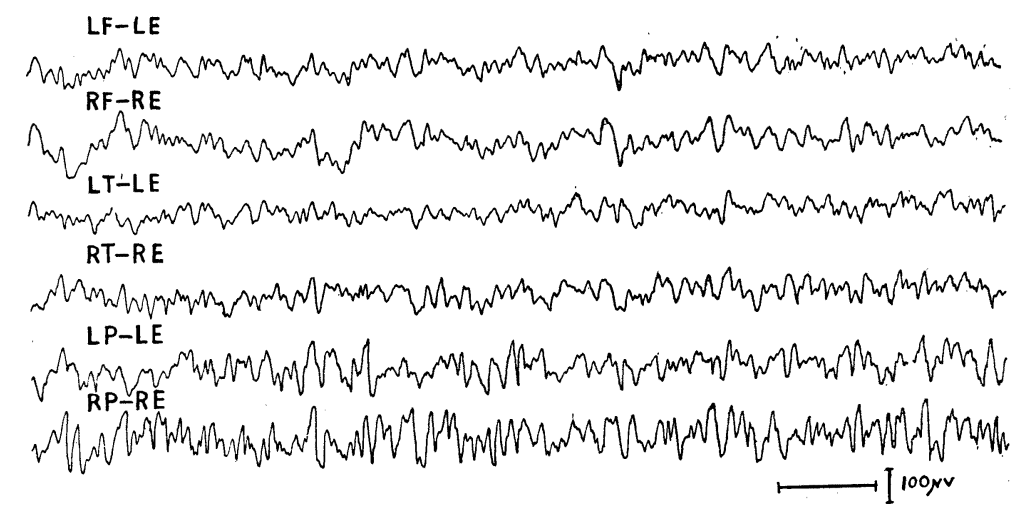

Fig. 158. The E.E.G. findings of case 3, taken in improved stage of tetanic manifestation, on June 13th, 1953, show that general pattern of rhythms is improved. There still remains an asymmetry which is irregular in the left side. However, no paroxysmal abnormal waves are found, compared with the previous E.E.G.

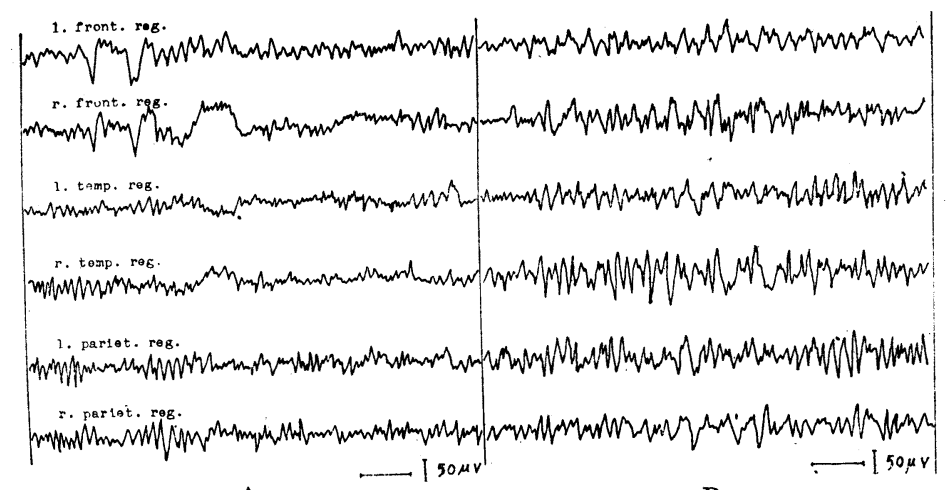

A

B

Fig. 159. Case 4. The E.E.G. in a severe rachttic child aged 3 years 2 months, before and after the tetanic provocation.

A : In the stage of 3 rd rachitic manifestation, showing regular continuous slow waves, $6-8 \mathrm{c} / \mathrm{s}$, in all leads before the tetanic provocation.

B : After the tetanic provocation, showing atypical spike and wave complex $3 \mathrm{c} / \mathrm{s}$ localized in frontotemporal area. Basic pattern : 5-6 c/s, These abnormalities which are commonly considered epileptic seizure resulted from the tetanic provocation.

Case 5: G. H. A male infant aged one year, weighing $3.500 \mathrm{~g}$ at birth. He was born in normal delivery with full term. He was breast fed until one month of age. At 2 months old he became mixed fed, supplied with mother's milk twice and pure cow's milk 3 times a day. Since 3 months of age, his mother nursed him with too much diluted cow's milk. He was reared in a room of poor sunshine, and kept in a bed all day until 4 months of his age.

On Dec. 4th, 1953, he was admitted to our clinic. 


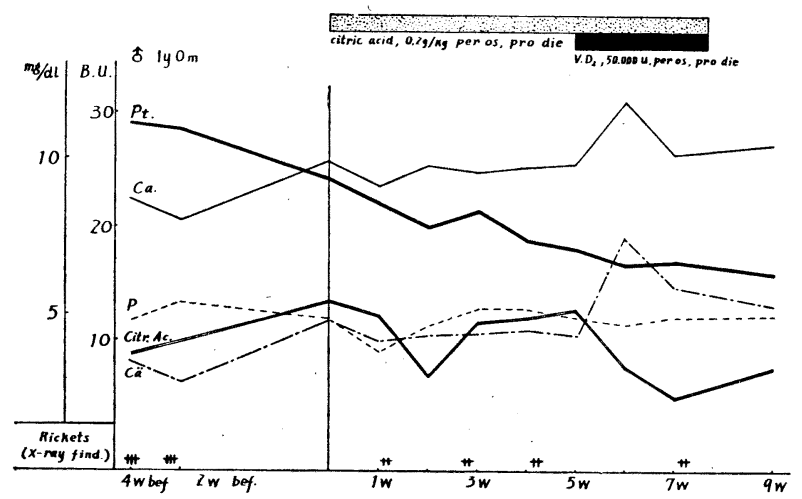

Fig. 160. Variation of Serum Ca, Ca\#, $\mathrm{P}, \mathrm{Al}-\mathrm{Ph}$, and Citric Acid in Vitamin $\mathrm{D}_{2}$ and Citric Acid Therapy.

A

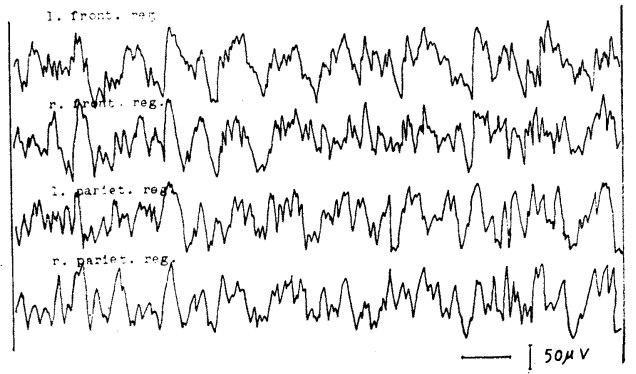

B

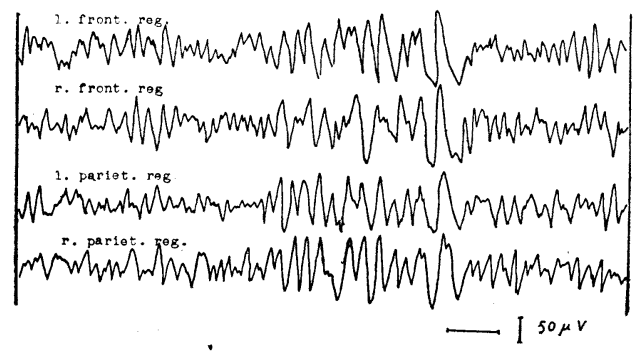

Fig. 161. The E.E.G. in a severe rachitic infant, associated with latent tetany, aged 3 years.

A : Before the treatment of vitamin $D_{2}$, dysrhythmic high voltage slow waves, $1.5-2 \mathrm{c} / \mathrm{s}$, and slight asymmetry is found.

B : After vitamin $D_{2}$ treatment, basic pattern of $4-5 \mathrm{c} / \mathrm{s}$, which means distinctly improved features, generally without asymmetry, and paroxysmal high voltage slow waves: $3 \mathrm{c} / \mathrm{s}$, which show themselves within the stage of a decreased threshold for convulsion, is found.
On admission physical examination revealed; $7.69 \mathrm{Kg}$ in weight, bad nourished, marked rosary, craniotabes, widely opened fontanel, enlarged distal end of bone, lordosis in spine and bow legs. Roentogenograms of skeleton revealed severe rachitic changes.

Variation of chemical findings of the patient in serum calcium, ionized calcium, phosphorus, alkaline phosphatase, and citric acid was as shown in Fig. 160. On admission, serum calcium : $7.95 \mathrm{mg}_{i}^{\prime} \mathrm{dl}$; ionized calcium $2.95 \mathrm{mg} / \mathrm{dl}$. They proved to be very low level. Phosphorus ; $4.32 \mathrm{mg} / \mathrm{dl}$, alkaline phosphatase : 29.13 B.U. markedly high value, magnesium $1.5 \mathrm{mg} / \mathrm{dl}$, slight lowered. Electrical threshold was slightly decreased contrary to our expectation. E.E.G. findings of this dystrophic severe rachitic infant were as shown in Fig. 161.

Though the E.E.G. before vitamin $\mathrm{D}_{2}$ treatment revealed dysrhythmic high voltage slow waves of $1.5-2 \mathrm{c} / \mathrm{s}$ in all leads, 
the electroencephalographic pattern in improving stage of rickets, showed regular slow waves of $4-5 \mathrm{c} / \mathrm{s}$ in basic pattern without asymmetry, as recognized in previous E.E.G.

It's findings after vitamin $\mathrm{D}_{2}$ treatment proved to be improved.

\section{Discussion}

It is a possible explanation that the hypocalcemia in rickets could be averted by increasing the activity of the parathyroid glands which maintain serum calcium above the tetany level. It is assumed that when the parathyroids fail to respond to stimulus of low serum calcium and fail to increase their activity in sufficient extent to the normal state of calcium level or they fall into dysfunction, and when insidious parathyroid insufficiency is accidentally accompanied with rickets and the definite deficit of calcium resorption is presented, the serum calcium falls below the critical level and hypocalcemic tetany will result.

Tetany without epileptic convulsion in case 1 may be associated with the respiratory infection, as a causative factor, already afflicted with high grade hypocalcemia due to severe rickets without vitamin $D_{2}$ intake before the onset of the illness.

Flensborg et al. $(1953)^{4)}$ reported on the occurrence of 62 cases who were suffered from tetany out of 615 patients with infantile rickets.

The report by Lubenstein $(1949)^{5)}$ described that the neonatal tetany in twins was coincident with maternal toxemia.

A study of Kebrer's original report $(1913)^{6}$ ) on tetany in the newborn showed that the maternal toxemia during pregnancy merited consideration as a possible etiologic factor.

Paffrath et $a l .^{8)}$ report an increased mineralization in the premature infant on a high calcium diet even without an addition of vitamin $\mathrm{D}_{2}$. It appears that the premature infant can absorb and retain a large amount of dietary calcium. A history of low milk intake and presumably low calcium content was recorded in our cases 2 and 3 . It is considered that rickets in cases 2 and 3 was induced by these conditions and associated with insufficiency of the regulation of calcium, especially considerable insufficiency in parathyroid. An E.E.G. showed coincident features of slow waves, sporadic high voltage slow waves, and cerebral dysrhythmia with occasionally spiking in all 3 cases.

Gotta et al. ${ }^{1)}$ reported that the most striking abnormality in the E.E.G. of parathyroid insufficiency occurred with high voltage slow waves $(2-5 \mathrm{c} / \mathrm{sec})$.

It is widely known that thyreoidectomy is followed by typical attacks of epilepsy alternating with tetany, and probably there is a disturbance in the physicochemical structure of brain cells which is not localized in a certain cerebral foci but extends throughout the cortex, as shown in the E.E.G. of case 1.

The E.E.G. also showed the essential difference between the mechanism of an epileptic seizure and that which produced an attack of tetany. In the former there is a disturbance in the electrical activity of the cortical brain cells : in the latter the E.E.G. shows potential difference originating in the muscles superimposed on the record of cerebral activity. 
Hansted et al. (1953) ${ }^{3)}$ reported that in two siblings with idiopathic hypoparathyroidism the E.E.G. showed wide spread slow activity, which disappeared after the serum calcium level had returned to normal values. One of them suffered from rickets.

By Klotz et al. $(1955)^{2)}$ also described that electroencephalographic changes in 2 cases of rachitic tetany showed predominant slow waves with sporadic spikies during hypocalcemia and could be suppressed by treatment with vitamin $\mathrm{D}$ and calcium chloride.

The electroencephalograms of Case 1 who showed predominant slow waves and dysrhythmia with sporadic spiky wave during the tetanic manifestation which gradually were reduced to the previous abnormal waves in accordance with the clinical signs and laboratory findings. It was recognized that the slight abnormalities was found even in the latent stage of tetany. The E.E.G. taken before and after the provocation test of tetany in infantile rickets were as shown in Fig. 159.
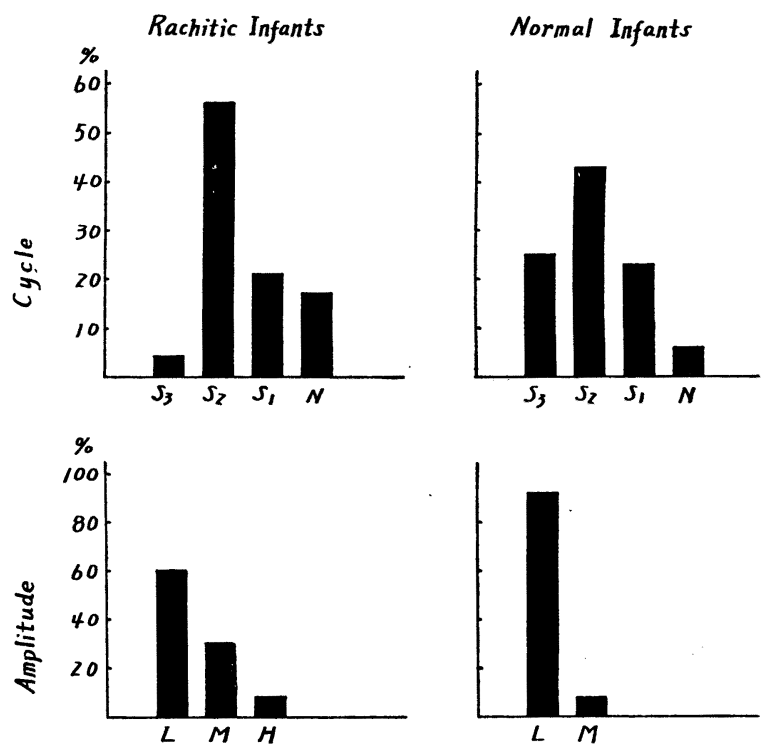

$$
\begin{aligned}
& \mathrm{S}_{3}: \quad 2 \sim 4 \mathrm{cps} \\
& \mathrm{S}_{2}: \quad 4 \sim 6 \mathrm{cps} \\
& \mathrm{S}_{1}: \quad 6 \sim 8 \mathrm{cps} \\
& \mathrm{N}: \quad 8 \sim 12 \mathrm{cps}
\end{aligned}
$$$$
\mathrm{L}: \text { under } 50 \mu \mathrm{V}
$$$$
\mathrm{M}: \quad 50 \sim 100 \mu \mathrm{V}
$$

$\mathrm{H}$ : above. $100 \mu \mathrm{V}$

Fig. 162. The differences of the E.E.G. findings between 6 cases of normal infants and 20 cases of rachitic infants. In normal infants the E.E.G. show $25 \%$ of $\mathrm{S}_{3}$ waves, $43 \%$ of $\mathrm{S}_{2}$ waves, $23 \%$ of $\mathrm{S}_{1}$ waves, and $6 \%$ of normal waves. In amplitude low voltage waves are shown in large amount.

The characteristic features in the E.E.G. of rachitic infants are $56 \%$ of $\mathrm{S}_{2}$ waves, $4 \%$ of $\mathrm{S}_{3}$ waves and more frequent appearances of high voltage waves than in the E.E.G. of normal infants. 
Before the provocation test of tetany ${ }^{11)}$ the E.E.G. showed generally a regular slow wave of $6-8 \mathrm{c} / \mathrm{sec}$ in rachitic infant. After the provocation test an atypical spike and wave complex appeared, which were localized in right frontotemporal area, with $5-6 \mathrm{c} / \mathrm{sec}$, slow waves in the basic pattern.

Abnormal activity of epileptic seizure by provocation appeared in E.E.G. In severe rickets a dysrhythmic slow wave burst, $1.5-2 \mathrm{c} / \mathrm{sec}$ and the difference of both side were found before treatment with vitamin $\mathrm{D}_{2}$. (Fig. 161). After the treatment the E.E.G. showed a basic pattern $4-5 \mathrm{c} / \mathrm{sec}$, which improved distinctly, no difference of both sides, and paroxysmal slow wave complex of $3 \mathrm{c} /$ sec appeared, which were referred to in the stage of a decreased threshold for convulsion.

The differences of the E.E.G. findings between normal infants and rachitic infants in our clinic, are presented in Fig. 162. The characteristic features in the E.E.G. of rachitic infants were the increase of $S_{2}$ waves, the decrease of $\mathrm{S}_{2}$ waves, and more frequent appearances of high voltage waves than in the E.E.G. of normal infants.

In our cases of rickets tetanic fits may be induced probably by idiopathic or secondary parathyroid insufficiency. It may be considered that such electroencephalographic changes are one of the important factor in determining whether rickets may be complicated by latent tetany or not.

\section{SUMMARY}

The present reports describe three cases of rickets associated with tetany. Especially, E.E.G. findings showed the appearance of epileptic seizure sporadic slow wave in series, paroxysmal dysrhythmia and sharp wave complexs occasionally in normal value. In Case 1, a dystrophic severe rickets was complicated by tetanic manifestation which was induced by high grade hypocalcemia. The hypocalcemia may be increased by mild respiratory infection and may fall in dysfunction by parathyroid insufficiency. An E.E.G. in Case 1 revealed the features of slow activity which improved distinctly after treatment with vitamin $\mathrm{D}_{2}$ and $\mathrm{Ca}$.

In Cases 2 and 3 or the premature infant whose history of low milk intake were recorded, tetany may be considered to depend upon hypocalcemia resulting from a previous condition rather than from rickets itself as causative factor: it may be idiopathic hypoparathyroidism.

In Case 3 the first administration of vitamin $\mathrm{D}_{2}$ may be considered to decrease electrical threshold for convulsion.

In case 4 , severe rickets, a marked change in E.E.G. by tetanic provocation was disclosed. This case was associated with latent tetany, and after the provocation test abnormal waves in E.E.G. were elicited.

The E.E.G. of the case 5, dystrophic severe rickets, showed abnormal waves in it's E.E.G., disaffearing after vitamin $\mathrm{D}_{2}$ treatment. 


\section{References}

1) Gotta, H. and Odoriz, J. B., J. Clin. Endocrinol., 1948, 8, 687. 2) Klotz, H. P. an Attal, Cl., Arch. Franc. Pediat., 1955, 12, 398. 3) Hansted, Chr. and Brandt, S., Electroenceph. Clin. Neurophysiol., 1953, 5, 101. 4) Flesborg, E. W. and Thamdrup, E., Ugeskr. Laeg., 1953, 13, 1237. 5) Lubenstein, H., J. Pediat., 1949, 35, 210.6 6) Kehrer, E., Ach. f. Gynäkolog., 1913, 99, 372. 7) Walton, R. L., Pediat., 1954, 13, 327. 8) Paffrath, H. and Massart, J., Z. f Kinderh., 1933, 53, 343. 9) Klotz, H. P., Arch. Franc. Pediat., 1955, 12, 401. 10) Peterman, M. G., Am J. Dis. Child., 194 72, 339. 11) Sano, T., Acta Paed. Jap., 1954, 58, 733. 